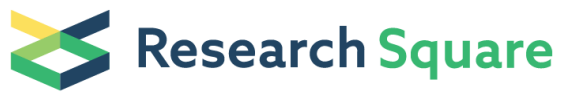 \\ Preprints are preliminary reports that have not undergone peer review. \\ They should not be considered conclusive, used to inform clinical practice, or referenced by the media as validated information.
}

\section{Characterization and Genome Sequence of a Genetically Unique Escherichia Bacteriophage vB_EcoM_IME392}

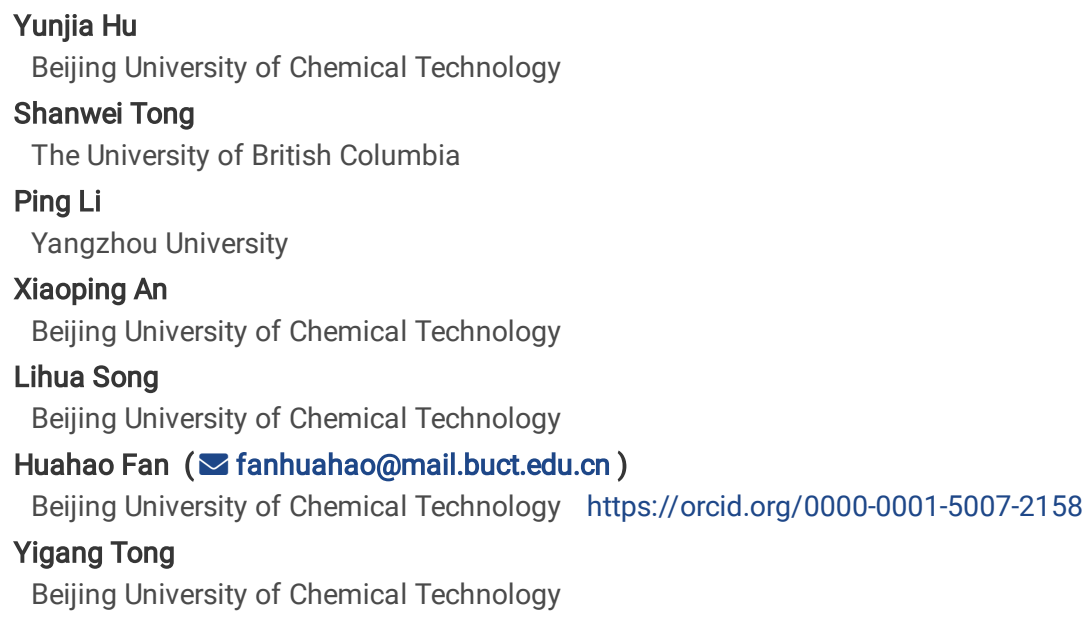

\section{Research Article}

Keywords: Escherichia coli-specific bacteriophage vB_EcoM_IME392, electron microscopy, German pediatrician Theodor Escherich isolated Posted Date: March 22nd, 2021

DOI: https://doi.org/10.21203/rs.3.rs-306526/v1

License: (ㅇ (1) This work is licensed under a Creative Commons Attribution 4.0 International License. Read Full License

Version of Record: A version of this preprint was published at Archives of Virology on July 8th, 2021. See the published version at https://doi.org/10.1007/s00705-021-05160-5. 


\section{Abstract}

In this study, a novel Escherichia coli-specific bacteriophage vB_EcoM_IME392 was isolated from chicken farm sewage in Qingdao, China. The genome of IME392 sequenced by Next Generation Sequencing is found to contain 116,460 base pairs in length with a G+C content of $45.4 \%$ (deposited in GenBank under the accession MH719082). BLASTN results reveal that only $2 \%$ of the genome sequence of IME392 shows homology to known phage sequences in GenBank, which indicates IME392 is a very novel bacteriophage. Transmission electron microscopy showed that IME392 belongs to the family Myoviridae. The host range, multiplicity of infection and one-step growth curve was also determined.

\section{Introduction}

Since the German pediatrician Theodor Escherich isolated E. coli from healthy human feces in 1885, it has been extensively and thoroughly studied [7, 8 , $21,22,24]$. Escherichia coli, as a model organism, currently plays a vital role in life science research and biotechnology industries such as pharmaceuticals and industrial chemicals $[5,13,18]$. E. coli is an important microorganism ubiquitous in the natural environment and mammalian gastrointestinal tract, and is part of the normal intestinal flora. E. coli and other facultative anaerobes constitute about $0.1 \%$ of gut microbiota [9]. Most $E$. coli are harmless, but certain serotypes can cause severe food poisoning, septic shock, meningitis, or urinary tract infections [16, 29], which seriously threaten human life and property safety. The discovery and use of antibiotics alleviated this situation, but at the same time, antibiotic abuse has brought a new challenge to clinical treatment-antibiotic resistance. There have been reports of strains resistant to all major antibiotic types in $E$. coli, including extended-spectrum-beta-lactams, carbapenems, fluoroquinolones, aminoglycosides, trimethoprim-sulfamethoxazole [28]. Recently, even plasmidmediated colistin resistance has emerged [23]. Due to the prevalence of multidrug resistant bacteria, bacteriophages that can lyse bacteria [14] seem to be a promising solution to this issue. After discovered by Twort and D'Hérelle, phages were soon used to treat bacterial infections. Phage therapy has certain advantages over antibiotic therapy: low cost, easy availability, specificity, and low side effects.

Bacteriophages are the most widespread living entities in nature, and their number is ten times more than that of bacteria. In co-evolution with the host, bacteriophages have produced tremendous diversity. The genome of Escherichia coli phage MS2 with 3,569 nucleotides of positive-sense single-stranded RNA is the first genome to be completely sequenced [10]. The following year, Sanger completed the sequencing of the $\Phi-X 174$ bacteriophage, which is the first DNA genome to be sequenced [30]. M13 is a filamentous bacteriophage composed of circular single-stranded DNA (ssDNA) which is 6,407 nucleotides long encapsulated in approximately 2,700 copies of the major coat protein P8, and capped with 5 copies of two different minor coat proteins (P9, P6, P3) on the ends [26]. In 1951, Esther Lederberg serendipitously discovered that after ultraviolet irradiation, the laboratory Escherichia coli K-12 strain released a bacteriophage that was later named lambda. Subsequently, the entire life cycle of its lysis and lysogen has been deeply studied. In addition, bacteriophages with large genome such as T2, T4, T5 and T6 have also been studied in many aspects. Among them, the T4-like phages are the most representative and the widely studied phages with large genome. The genomes of these phages are more than $100 \mathrm{~kb}$ and encode $100-300$ or even more kinds of proteins and a variety of tRNAs. Most of these large genome phages share the well-organized and highly conserved core genes, especially those encode DNA replication and virion structural proteins $[6,27]$. The research on these known phages will help us understand and discover the mysteries of life, and provide guidance for future research.

Thanks to the rapid development of high-throughput sequencing technology, the phage sequence in GenBank has grown geometrically. However, most of the phage sequences in GenBank have a high degree of homology with known bacteria or phage, while phage with lower homology are rare. In this study, we isolated and identified a genetically unique Escherichia coli phage, whose genome is only $2 \%$ homologous to the phage in GenBank, indicating that it may have completely different characteristics and functions from the existing phage.

\section{Materials And Methods}

\section{Sampling, Isolation and Purification of Escherichia Phage IME392}

Phage IME392 and its host cell, Escherichia coli E2, were isolated from sewage samples taken from a chicken farm in Qingdao, China. For the purification of phage particles, the sewage samples were firstly centrifuged at 12,000×g for 5 min and then filtered through a $0.22-\mu \mathrm{m}$ membrane. After that, an equal amount of the filtrate was added to the $3 \times \mathrm{LB}$ medium containing the log-phase host bacteria $\mathrm{E} 2\left(\mathrm{OD}_{600}=0.4\right)$, and cultured overnight at $37^{\circ} \mathrm{C}, 180 \mathrm{rpm}$. The culture was centrifuged at $12,000 \times \mathrm{g}$ for 5 minutes and precipitation was discarded while the supernatant was filtrated by passing through a $0.22-\mu \mathrm{m}$ filter to remove host cells. The filtrate was serially diluted with sterile PBS in a 10-fold dilution method, and then $100 \mu \mathrm{L}$ of the dilution was mixed with $200 \mu \mathrm{L}$ of the log-phase host bacteria culture, followed by incubation at room temperature for 5 minutes. The mixture was added to $5 \mathrm{~mL}$ of preheated $0.75 \%$ LB soft agar, and poured on the surface of $1.5 \%$ hard agar plates. After solidification, the plates were incubated at $37^{\circ} \mathrm{C}$ overnight. Single plaques were isolated from the plates and again incubated over night with a liquid culture of $\mathrm{E} 2$ with shaking at $37^{\circ} \mathrm{C}$. Cultures were re-centrifuged, sterile filtrated and the filtrates were subjected to another round of plaque assays. This process is repeated three times to obtain pure phage stocks.

\section{Multilocus sequence typing}

According to the previous reports [15], primer pairs for eight housekeeping genes including $\operatorname{din} B$, icd $A, \operatorname{pab} B, \operatorname{pol} B, p u t P, \operatorname{trp} A$, $\operatorname{trp} B$ and $u i d A$ were $\operatorname{designed}$ for PCR amplification. All PCR products were purified by gel extraction and then sequenced by Beijing Ruiboxingke Biotechnology Co., Ltd. using universal sequencing primer OF and/or OR. Further details on this MLST scheme can be found at http://www.pasteur.fr/mlst.

DNA Extraction, Gene Sequencing and Bioinformatic Analysis 
According to a modified standard phenol-chloroform extraction protocol [34], DNase I and RNase A (Thermo Scientific, USA) with a final concentration of $1 \mu \mathrm{g} / \mathrm{mL}$ were added to the purified phage IME392 stock solution and incubated overnight at $37^{\circ} \mathrm{C}$. After incubating at $80{ }^{\circ} \mathrm{C}$ for 15 minutes to inactivate DNase I and cooling down to room temperature, the lysis buffer with a final concentration of $0.5 \%$ SDS, $50 \mu \mathrm{g} / \mathrm{ml} \mathrm{protease} \mathrm{K}$ and $20 \mathrm{mM}$ EDTA was added. The solution was incubated for 1 hour at $56^{\circ} \mathrm{C}$, and added an equal volume of Tris-saturated phenol. The mixture was vortexed to form a uniform emulsion. After $10,000 \times \mathrm{g}$ centrifugation at $4{ }^{\circ} \mathrm{C}$ for 5 minutes, the upper aqueous phase was collected and transferred to a new tube, while also adding an equal volume of extraction agent (phenol: chloroform: isoamyl alcohol= 25:24:1). The mixture was centrifuged again ( $\left.10,000 \times \mathrm{g}, 4^{\circ} \mathrm{C}, 5 \mathrm{~min}\right)$, and the aqueous phase was collected and added to an equal volume of isopropanol. The mixture was incubated at $-20^{\circ} \mathrm{C}$ for more than 1 hour, followed by $10,000 \times$ g centrifugation at $4{ }^{\circ} \mathrm{C}$ for 20 minutes, precipitating phage DNA. The precipitation was collected and washed twice with $1 \mathrm{~mL}$ of $75 \%$ cold ethanol, then resuspended in $30 \mu \mathrm{L}$ of deionized water and stored at $-20^{\circ} \mathrm{C}$.

According to the manufacturer's instructions, a $2 \times 300$ nt paired-end DNA library was prepared using NEBNext ${ }^{\circledR}$ Ultra ${ }^{T M}$ II DNA Library Prep Kit for Illumina ${ }^{\circledR}$. The Bioruptor UCD-200TS ultrasound system is used to fragment a total volume of $50 \mu$ l DNA (about $100 \mathrm{ng}$ ) into $300-600$ bp fragments. The resulting fragmented DNA was end repaired and ligated to NEBNext adaptor. Cleanup of Adaptor-ligated DNA was used AMPure XP Beads. Finally, the cleaned DNA was amplified by PCR for 4 to 5 cycles, and the PCR product was purified again using AMPure XP Beads. Agilent 2100 Bioanalyzer system was used to measure the size distribution of the constructed library fragments, and the library was quantified using the KAPA Library Quantification Kits. Whole genome sequencing was performed on Illumina Miseq sequencing platform (San Diego, CA, United States) with a 600-cycle MiSeq v3 Reagent kit to generate $2 \times 300$ bp paired-end reads. Overall, 555,564 raw reads were generated.

The raw sequencing data quality was analyzed using the quality control software FastQC v0.11.5 and filtered for low quality reads and adapter regions using Trimmomatic 0.36 with default parameters [4]. The generated high-quality reads were assembled by SPAdes v3.13.0 with default parameters and approximately 4,872 contigs were generated [3]. For the assembled contigs, Bandage v0.8.1 [31], which is a tool for visualizing assembly graphs with connections, was used to display the connections between those contigs. Among them, only 3 contigs are circularity with lengths of $116,460,39,440$ and 4,888 bp respectively and coverage of $352 \times, 7 x$ and $18 \times$ respectively. By BLASTn analysis, it is confirmed that the two shorter contigs are lysogenic phage and plasmid respectively. The mapping was carried out with CLC Genomics Workbench 12.0.2 (Length fraction $=0.95$; Similarity fraction $=0.95$ ) which was also used to adjust the sequences and for result checking. A consensus genome was generated that spanned $100 \%$ of the reference genome and the 425,959 mapped reads had an 884.1 mean read coverage. Nucleic acid sequence similarity search was performed by BLASTn

(https://blast.ncbi.nlm.nih.gov/Blast.cgi). Gene annotation was first run on RAST [2] (http://rast.nmpdr.org/), then refined by amino acid sequence comparisons on BLASTp. The genome function map was generated by the laboratory's self-built script and optimized using Inkscape 0.92 .1 .

The amino acid sequence of the major capsid protein and the terminase large subunit of the bacteriophage IME392 was used to construct a neighborjoining phylogenetic tree via MEGA 7.0 with 1000 bootstrap replicates and optimized by online website tool EvolView

(https://www.evolgenius.info/evolview/).

\section{Transmission Electron Microscopy}

After centrifuging the co-culture of the phage and its host at $12,000 \times \mathrm{g}$ and filtering with a $0.22-\mu \mathrm{m}$ filter, the phage particles were purified by sucrose density gradient centrifugation [33]. Approximately $20 \mu \mathrm{L}$ purified, enriched phage sample were deposited on carbon-coated copper grids for a 15 minutes absorption and then dried using filter paper. The phage particles were negatively stained by $2 \%(\mathrm{w} / \mathrm{v})$ phosphotungstic acid ( $\mathrm{pH} 7.0)$ for 2 min, and examined using a JEM-1200EX transmission electron microscope (Jeol Ltd., Tokyo, Japan) at the acceleration voltage of $80 \mathrm{kV}$.

\section{Host Range Determination}

The host range of phage IME392 was determined by spot assay and was confirmed with the plaque assays. Suspected hosts were cultured at $37{ }^{\circ} \mathrm{C}$ to reach the optical density of 1.0 . $300 \mathrm{~mL}$ of bacterial cultures was added to $5 \mathrm{~mL}$ of preheated $0.7 \% \mathrm{LB}$ agar, and poured on $1.5 \%$ agar plates respectively. After solidification, each plate was examined by pipetting $5 \mu \mathrm{L}$ phage suspension onto the bacterial lawn. Eligible hosts are detected by plaque formation after incubating overnight at $37^{\circ} \mathrm{C}$. The plaque assay procedure is as described in the phage purification section.

\section{Determination of Optimal Multiplicity of Infection}

Multiplicity of infection (MOI), or the ratio of phage particles to bacteria cells prior to culture, affects the final production of bacteriophages. At optimal $\mathrm{MOI}$, the cultured product contains the largest amount of phage particles after reaching stationary phase. In order to determine the optimal MOI, firstly, the colony forming unit of the log-phase $\left(\mathrm{OD}_{600}=0.6\right)$ host bacteria $\mathrm{E} 2$ culture and the plaque forming unit of the bacteriophage IME392 stock solution were calculated separately. The bacteria-phage mixture was added to $5 \mathrm{~mL} L B$ medium according to different ratios to achieve a MOI of $10,1,0.1,0.01,0.001$, or 0.0001 , which were subsequently incubated at $37^{\circ} \mathrm{C}, 220 \mathrm{rpm}$ for 4 hours. After centrifuging at $12,000 \times \mathrm{g}$ for $1 \mathrm{~min}$ and filtering the culture through a $0.22-\mu \mathrm{m}$ filter, the phage titer was calculated using the double-layer plate method after serial dilution. Three replicates were conducted for determination and the $\mathrm{MOI}$ produced the highest phage titer was considered the best $\mathrm{MOI}$ of the phage.

\section{One-step Growth Curve}

The one-step growth curve was examined by the following method. A mixture of phage and bacteria at optimal $\mathrm{MOI}(0.1)$ was allowed to incubate in 37 ${ }^{\circ} \mathrm{C}$ for 10 minutes for absorption. After centrifugation at $12,000 \times \mathrm{g}$ for $1 \mathrm{~min}$, the supernatant which contained the unabsorbed phage particles were discarded, while the precipitation was then washed twice with LB medium and re-suspended in $20 \mathrm{~mL}$ of LB medium. The moment when the precipitation 
was re-suspended in medium was defined as time zero. The obtained culture was subsequently transferred to a shaker and cultured at $37^{\circ} \mathrm{C}$, $220 \mathrm{rpm}$ for $140 \mathrm{~min}$. The $200 \mu \mathrm{L}$ samples were collected every 10 minutes (every 5 minutes in the first 30 minutes) and then centrifuged and plated on double agar plates to determine the phage titer. Each sample were plated on 3 separate plates respectively. Finally, the one-step growth curve was plotted by Graphpad Prism 8.0.

\section{Determination of $\mathrm{pH}$ and Temperature Tolerance}

To determine the tolerance of phage particles to different $\mathrm{pH}$, LB medium were adjusted to a variety of $\mathrm{pH}(2.0,3.0,4.0 \ldots 13.0)$ with $5 \mathrm{M} \mathrm{HCl}$ or $\mathrm{NaOH}$ solution and then filtered through a $0.22-\mu \mathrm{m}$ filter. $100 \mu \mathrm{l}$ purified phage suspension were added into the $900 \mu \mathrm{l} \mathrm{LB}$ medium of different pHs and incubated at $37^{\circ} \mathrm{C}$ for 1 hour. To investigate the thermal stability of the phage, $100 \mu$ l purified phage suspension were added to $900 \mu \mathrm{LB}$ medium and incubated at a variety of temperatures $\left(30^{\circ} \mathrm{C}, 37^{\circ} \mathrm{C}, 40^{\circ} \mathrm{C}, 50^{\circ} \mathrm{C}, 60^{\circ} \mathrm{C}, 70^{\circ} \mathrm{C}, 80^{\circ} \mathrm{C}\right)$ for 1 hour. The titer of the remaining viable phage particles was determined using the double-layer agar method. All assays were performed in triplicate.

\section{Proteomic Analysis}

The phage particles were concentrated by PEG and then purified by sucrose density gradient centrifugation [33]. Purified phages were mixed with $6 \times$ protein loading buffer (TransGen Biotech Co., LTD) and then boiled for 10 minutes, followed by concentrating at $12,000 \times \mathrm{g}, 4^{\circ} \mathrm{C}$ for 3 min. The proteins were separated by $12 \%$ SDS-PAGE (Sodium Dodecyl Sulfate Polyacrylamide Gel Electrophoresis) and the bands were visualized by staining the gels with Coomassie brilliant blue. Gel slices were then excised and trypsinized. Briefly, $2.5 \mu \mathrm{g}$ Trypsin enzyme was added to $100 \mu \mathrm{g}$ protein solution according the ratio of protein:enzyme $=40: 1$, and enzymatically digested at $37^{\circ} \mathrm{C}$ for 4 hours. Add Trypsin one more time according to the above ratio, and continue enzymatic digested at $37^{\circ} \mathrm{C}$ for 8 hours. The enzymatically digested peptides are desalted by Strata X column and vacuumed to dry. The dried peptide sample was analyzed by using Liquid chromatography-mass spectrometry (LC-MS). The full spectrum identification of protein is mainly based on experimental tandem mass spectrometry data, matching with theoretical mass spectrometry data obtained by database simulation, so as to obtain protein identification results. First the original mass spectrum data was converted into a mass spectrum peak file, and then searched and matched the sequence in the database using Mascot v2.3.02 (parameter: Enzyme Trypsin, Fragment Mass Tolerance 0.05 Da, Fixed modifications Carbamidomethyl (C), Variable modifications Oxidation (M); GIn->pyro-Glu (N-term Q); Deamidated (NQ), Max Missed Cleavages 1, Instrument type ESI-FTICR, Database Bacteriophage_392_nr.fasta) and performed some filtering and quality control (Mascot evalue $<=0.05$ ) on the search results to give reliable protein identification results.

\section{Results}

\section{Morphological Features of Phage IME392}

After 10 hours of culture on double agar plates, the bacteriophage IME392 forms visible but small plaques, reaching around 0.3-0.5 millimeters in diameter. Transmission electron microscopy results suggest that bacteriophage IME392 is morphologically classified as Myoviridae, possessing an icosahedral head of approximately $83.93 \pm 0.55 \mathrm{~nm}$ in diameter $(n=10)$ and a contractile tail of $122.23 \pm 3.55 \mathrm{~nm}$ in length ( $\mathrm{n}=10)($ Fig. 1$)$.

\section{Host range}

In this study, the ability of bacteriophage IME392 to lyse strains was determined by the spot assay as well as plaque assay. The host range test was conducted on 33 clinically isolated pathogenic strains or environmentally isolated strains, including 28 E. coli strains, as well as other bacteria consisted of Salmonella. As the results are shown in Table 1, among 28 strains of E. coli, only 5 strains produced bright and clear plaques and the plaque formed on the lawns of 8 strains was slightly turbid. The phage couldn't infect other $15 \mathrm{E}$. coli strains and strains from other species. This indicates that the bacteriophage IME392 has a relatively narrow and more specific host range.

\section{Physiological Features of Phage IME392}

The optimal $\mathrm{MOI}$ was determined as 0.1 , and it was the original phage to host cell ratio of the one-step growth curve experiment. The one-step growth curve of IME392 is shown in figure 2. It can be observed that the latent period and burst period are both approximately 15 minutes. In comparison with other known phages [11, 12, 19, 35], IME392 has lower phage titer when reaching stationary phase, at about $10^{8}$ plaque forming units per milliliter $(\mathrm{PFU} / \mathrm{mL})$, and this result is consistent with the small plaque size of IME392.

The temperature and pH stability of IME392 phage particles are shown in figures 3A and 3B, respectively. IME392 is extremely sensitive to heat treatment. Incubating up to $60^{\circ} \mathrm{C}$ for 1 hour is able to reduce phage titer by $99.94 \%$, while no phage titer was observed if the incubation temperature reached $70{ }^{\circ} \mathrm{C}$ or higher. IME392 is also sensitive to both low and high pH environment. No live phage was detected when the phage particles were incubated in pH $=2.0$ or 13.0 environment at $37^{\circ} \mathrm{C}$ for 1 hour.

\section{Genome Sequencing and Analysis}

The complete genome sequence of phage IME392 consists of 116,460 base pairs in length, with a GC content of $45.4 \%$. 160 potential open reading frames (ORFs) were predicted by RAST. The genome sequence is submitted to Genbank (https://www.ncbi.nlm.nih.gov/genbank/), available to public access under the sequence ID MH719082.1. 
The genome sequence of IME392 was analyzed by BLASTN. Results have revealed that only $2 \%$ of the genome sequence $(91,907-94,497)$ are homologous to known nucleotide sequences in public databases. Homologous sequences contain both phage and bacterial sequences. The 89 potential CDS were further analyzed by BLASTP, among which 34 were identified as functional protein, including 15 morphogenesis-related protein, 16 replicationrelated protein, and 5 lysis-related protein. Two tailspikes were classified as both morphogenesis and lysis related protein. 23 ORFs encoding proteins are highly homologous to phage protein of unknown function, and 2 others are only homologous to bacterial hypothetical protein. The products of the remaining 30 ORFs have no significant homology to proteins from the public database. The annotated genes were shown on the genome function map (Fig.4) and Table 2.

The replication-related modules of IME392 are mainly distributed in the 7,051-54,779 region of the genome, with a total length of about $47 \mathrm{~kb}$, which is about one-third of the length of the entire genome, and the length of the span is relatively rare. A total of 60 open reading frames are predicted in this region, of which 16 ORF-encoded proteins have known functions, 9 are hypothetical proteins, and the remaining 35 are not hit and have no homology with currently known proteins. The situation where the length span is particularly large may be related to a large number of non-homology proteins interspersed between genes encoding replication-related enzymes such as ligase, DNA polymerase, RNA polymerase, helicase and topoisomerase. The next two genes encode two tRNAs, Met (CAT) and Arg (TCT). Packaging-related, virion structure and lysis proteins are closely linked in the genome, covering the range of $61-104 \mathrm{~kb}$, and they are all located in the positive strand of the IME392 genome. This unique organization of the IME392 genome may be one of the reasons for its low homology with existing bacteriophages.

The major capsid protein and terminase large subunit were chosen for phylogenetic tree construction (Fig.5). In all cases, vB_EcoM_IME392 clustered with Vibrio phage Va2 and Vibrio phage 1.031.0._10N.261.46.F8 but belong to different branches, indicating that they may have a common ancestor. Vibrio phage Va2 was isolated from aquaculture waters in Qingdao, Shandong, China and IME392 was also isolated from Qingdao. This geographical similarity reveals that they may have an evolutionary connection. The Va2 genome is $128,360 \mathrm{bp}$ in length and carries a total of 134 open reading frames, which is basically the same as IME392. The 152,942 bp Vibrio phage 1.031.0._10N.261.46.F8 partial genome is larger than the two of them. Like IME392, 1.031.0._10N.261.46.F8 also has 2 tRNA genes [17]. However, the phylogenetic relationship with other phages is clearly distant, indicating that IME392 is a novel phage. Moreover, the bacteriophage IME392 presents an independent branch on the phylogenetic tree, and has low homology with the existing phages in the Myoviridae family, and can be classified as a new genus.

\section{Proteomic Analysis}

To identify the predicted proteins by our genomic analysis, the phage was concentrated and analysed using mass spectrometry. 60 proteins were identified and 28 out of these were identified as having homologs of known function (Table 3). Nine of the identified proteins can be categorized as structural proteins, proteins involved in the morphogenesis of the phage (CDS1, CDS3, CDS48, CDS53, CDS65, CDS66, CDS68, CDS69, CDS72). In addition to the terminase large subunit, all replication-related proteins were identified. However, only two lysis-related proteins were identified. The massspectrometry based proteomics identified 28 of the 34 proteins, predicted in our genomic analysis (Table 2), with a known function. In total, 60 out of 89 (67.4\%) predicted proteins were identified by mass-spectrometry proteomics, most of them encoded by identified structural genes.

\section{Discussion}

The invention of antibiotics has greatly improved the living conditions of mankind and saved tens of thousands of lives. But at the same time, the problem of drug resistance and even multi-drug resistance caused by the antibiotics abuse has brought new challenges to mankind. And it was estimated that 700,000 people die from drug-resistant infections each year, and this number may rise to 10 million by 2050 . The speed of development of new antibiotics cannot match the speed of antibiotic resistance [20,25]. Phage therapy has gradually become a research hotspot due to its high efficiency, strong specificity, and easy availability. At present, a variety of phage preparations have been successfully developed and used in clinical treatment. In this study, we isolated and identified a new type of bacteriophage IME392 that can infect Escherichia coli. The phage can only infect part of the tested $E$. coli strains, but not other $E$. coli strains or strains from other species. In addition, no toxin genes, antibiotic resistance genes, phage lysogenic factors and other pathogen-related genes have been found in genes with known functions in the phage genome. However, the functions of many genes are still unknown, so it is important to identify the functions of these genes. The use of this phage to treat infections caused by resistant $E$. coli still has a long way to go.

Genomic analysis shows that the bacteriophage IME392 has low similarity with existing biological entities (only $2 \%$ ) and may have numerous uncharted features. The genome annotation of IME392 only revealed 13 predicted phage structural proteins, while the genes encoding other phage structural proteins are still unknown. In addition, the genome of phage IME392 also encodes a variety of replication-related proteins, including DNA polymerase, DNA ligase, DNA helicase, topoisomerase, 5'-3' DNA exonuclease and other replication-related proteins. Therefore, it can rely on its own encoding enzymes to replicate, we speculate that it may have its own replication mechanism. It is worth noting that we also found two genes encoding the DNAdirected RNA polymerase in the genome of the bacteriophage IME392, which is not common in bacteriophages.

Glycosyltransferase is an enzyme that can catalyze the transfer of the glycosyl moiety from the activated nucleotide sugar to the ribophilic glycosyl acceptor molecule [32]. Some bacteriophages modify the glycome by influencing the expression of host glycosyltransferases, while other phages are unique in that they can express their own glycosyltransferases. These bacteriophages glucosylate their DNA to protect it from host restriction endonuclease systems. Furthermore, glycosyltransferase may function in the puncturing or lysis of the cell wall peptidoglycan. We were surprised to find that the genome of the bacteriophage IME392 also contains a gene encoding glycosyltransferase, which may prevent it from the removal by the host, but its exact function in the life cycle of bacteriophage IME392 still needs further experimental verification. The Escherichia coli bacteriophage IME392

Page 5/18 
genome also encodes two distinct tailspike proteins. The tailspike protein of Enterobacteria phage P22 mediates the recognition and adhesion between the bacteriophage and the surface of Salmonella enterica cells [1]. It is speculated that the tailspike protein of bacteriophage IME392 has a similar function. We believe that the presence of glycosyltransferase and tailspike protein helps phage IME392 infect and adsorb the host more easily.

In conclusion, we present here the biology and genomic and proteomic characteristics of Escherichia coli phage IME392 isolated from sewage samples taken from a chicken farm in Qingdao, China. The newly isolated phage IME392 was assigned as a member of the Myoviridae family. The findings of this study not only provide new phage resources for the development of phage therapy against $E$. coli, but also show that there are still many completely novel phages waiting for our discovery and research in nature.

\section{Declarations}

\section{Acknowledgments:}

This research was supported by Key Project of Beijing University of Chemical Technology(No. XK1803-06), National Key Research and Development Program of China (2018YFA0903000, 2020YFC2005405, 2020YFA0712100, 2020YFC0840805), Funds for First-class Discipline Construction (No. XK1805), Inner Mongolia Key Research and Development Program (NO. 2019ZD006), National Natural Science Foundation of China (81672001, 81621005), NSFC-MFST project (China-Mongolia) (No. 31961143024), Fundamental Research Funds for Central Universities (No. BUCTRC201917, BUCTZY2022).

\section{Conflict of interest}

The authors declare that they have no conflict of interest.

\section{Ethical approval}

This article does not contain any studies with human participants or animals performed by any of the authors.

\section{References}

1. Andres D, Baxa U, Hanke C, Seckler R, Barbirz S (2010) Carbohydrate binding of Salmonella phage P22 tailspike protein and its role during host cell infection. Biochem Soc Trans 38:1386-1389

2. Aziz RK, Bartels D, Best AA, DeJongh M, Disz T, Edwards RA, Formsma K, Gerdes S, Glass EM, Kubal M, Meyer F, Olsen GJ, Olson R, Osterman AL, Overbeek RA, McNeil LK, Paarmann D, Paczian T, Parrello B, Pusch GD, Reich C, Stevens R, Vassieva O, Vonstein V, Wilke A, Zagnitko O (2008) The RAST Server: rapid annotations using subsystems technology. BMC Genomics 9:75

3. Bankevich A, Nurk S, Antipov D, Gurevich AA, Dvorkin M, Kulikov AS, Lesin VM, Nikolenko SI, Pham S, Prjibelski AD, Pyshkin AV, Sirotkin AV, Vyahhi N, Tesler G, Alekseyev MA, Pevzner PA (2012) SPAdes: a new genome assembly algorithm and its applications to single-cell sequencing. J Comput Biol 19:455-477

4. Bolger AM, Lohse M, Usadel B (2014) Trimmomatic: a flexible trimmer for Illumina sequence data. Bioinformatics 30:2114-2120

5. Chen X, Zhou L, Tian K, Kumar A, Singh S, Prior BA, Wang Z (2013) Metabolic engineering of Escherichia coli: a sustainable industrial platform for bio-based chemical production. Biotechnol Adv 31:1200-1223

6. Chibani-Chennoufi S, Canchaya C, Bruttin A, Brüssow H (2004) Comparative genomics of the T4-Like Escherichia coli phage JS98: implications for the evolution of T4 phages. J Bacteriol 186:8276-8286

7. Cohen SN, Chang AC, Boyer HW, Helling RB (1973) Construction of biologically functional bacterial plasmids in vitro. Proc Natl Acad Sci U S A 70:3240-3244

8. Crick FH, Barnett L, Brenner S, Watts-Tobin RJ (1961) General nature of the genetic code for proteins. Nature 192:1227-1232

9. Eckburg PB, Bik EM, Bernstein CN, Purdom E, Dethlefsen L, Sargent M, Gill SR, Nelson KE, Relman DA (2005) Diversity of the human intestinal microbial flora. Science 308:1635-1638

10. Fiers W, Contreras R, Duerinck F, Haegeman G, Iserentant D, Merregaert J, Min Jou W, Molemans F, Raeymaekers A, Van den Berghe A, Volckaert G, Ysebaert M (1976) Complete nucleotide sequence of bacteriophage MS2 RNA: primary and secondary structure of the replicase gene. Nature 260:500-507

11. Fu P, Zhao Q, Shi L, Xiong Q, Ren Z, Xu H, Chai S, Xu Q, Sun X, Sang M (2021) Identification and characterization of two bacteriophages with lytic activity against multidrug-resistant Escherichia coli. Virus Res 291:198196

12. Guo Z, Huang J, Yan G, Lei L, Wang S, Yu L, Zhou L, Gao A, Feng X, Han W, Gu J, Yang J (2017) Identification and Characterization of Dpo42, a Novel Depolymerase Derived from the Escherichia coli Phage vB_EcoM_ECO078. Front Microbiol 8:1460

13. Huang CJ, Lin H, Yang X (2012) Industrial production of recombinant therapeutics in Escherichia coli and its recent advancements. $J$ Ind Microbiol Biotechnol 39:383-399

14. Jassim SA, Limoges RG (2014) Natural solution to antibiotic resistance: bacteriophages 'The Living Drugs'. World J Microbiol Biotechnol 30:21532170 
15. Jaureguy F, Landraud L, Passet V, Diancourt L, Frapy E, Guigon G, Carbonnelle E, Lortholary O, Clermont O, Denamur E, Picard B, Nassif X, Brisse S (2008) Phylogenetic and genomic diversity of human bacteremic Escherichia coli strains. BMC Genomics 9:560

16. Kaper JB, Nataro JP, Mobley HL (2004) Pathogenic Escherichia coli. Nat Rev Microbiol 2:123-140

17. Kauffman KM, Brown JM, Sharma RS, VanInsberghe D, Elsherbini J, Polz M, Kelly L (2018) Viruses of the Nahant Collection, characterization of 251 marine Vibrionaceae viruses. Sci Data 5:180114

18. Kim B, Park H, Na D, Lee SY (2014) Metabolic engineering of Escherichia coli for the production of phenol from glucose. Biotechnol J 9:621-629

19. Kutter EM, Skutt-Kakaria K, Blasdel B, El-Shibiny A, Castano A, Bryan D, Kropinski AM, Villegas A, Ackermann HW, Toribio AL, Pickard D, Anany H, Callaway T, Brabban AD (2011) Characterization of a Vil-like phage specific to Escherichia coli 0157:H7. Virol J 8:430

20. Laxminarayan R, Amábile-Cuevas CF, Cars O, Evans T, Heymann DL, Hoffman S, Holmes A, Mendelson M, Sridhar D, Woolhouse M, Røttingen JA (2016) UN High-Level Meeting on antimicrobials-what do we need? Lancet 388:218-220

21. Linn S, Arber W (1968) Host specificity of DNA produced by Escherichia coli, X. In vitro restriction of phage fd replicative form. Proc Natl Acad Sci U S A 59:1300-1306

22. Liu T, Khosla C (2010) Genetic engineering of Escherichia coli for biofuel production. Annu Rev Genet 44:53-69

23. Liu YY, Wang Y, Walsh TR, Yi LX, Zhang R, Spencer J, Doi Y, Tian G, Dong B, Huang X, Yu LF, Gu D, Ren H, Chen X, Lv L, He D, Zhou H, Liang Z, Liu JH, Shen $\mathrm{J}$ (2016) Emergence of plasmid-mediated colistin resistance mechanism MCR-1 in animals and human beings in China: a microbiological and molecular biological study. Lancet Infect Dis 16:161-168

24. Luria SE, Delbrück M (1943) Mutations of Bacteria from Virus Sensitivity to Virus Resistance. Genetics 28:491-511

25. O'Neill J (2016) Tackling drug-resistant infections globally: final report and recommendations. Government of the United Kingdom

26. Opella SJ, Stewart PL, Valentine KG (1987) Protein structure by solid-state NMR spectroscopy. Q Rev Biophys 19:7-49

27. Petrov VM, Nolan JM, Bertrand C, Levy D, Desplats C, Krisch HM, Karam JD (2006) Plasticity of the gene functions for DNA replication in the T4-like phages. J Mol Biol 361:46-68

28. Pitout JD (2012) Extraintestinal pathogenic Escherichia coli: an update on antimicrobial resistance, laboratory diagnosis and treatment. Expert Rev Anti Infect Ther 10:1165-1176

29. Russo TA, Johnson JR (2003) Medical and economic impact of extraintestinal infections due to Escherichia coli: focus on an increasingly important endemic problem. Microbes Infect 5:449-456

30. Sanger F, Air GM, Barrell BG, Brown NL, Coulson AR, Fiddes CA, Hutchison CA, Slocombe PM, Smith M (1977) Nucleotide sequence of bacteriophage phi X174 DNA. Nature 265:687-695

31. Wick RR, Schultz MB, Zobel J, Holt KE (2015) Bandage: interactive visualization of de novo genome assemblies. Bioinformatics 31:3350-3352

32. Williams GJ, Thorson JS (2009) Natural product glycosyltransferases: properties and applications. Adv Enzymol Relat Areas Mol Biol 76:55-119

33. Yuan W, Zhang Y, Wang G, Bai J, Wang X, Li Y, Jiang P (2016) Genomic and proteomic characterization of SE-I, a temperate bacteriophage infecting Erysipelothrix rhusiopathiae. Arch Virol 161:3137-3150

34. Zhang Q, Xing S, Sun Q, Pei G, Cheng S, Liu Y, An X, Zhang X, Qu Y, Tong Y (2017) Characterization and complete genome sequence analysis of a novel virulent Siphoviridae phage against Staphylococcus aureus isolated from bovine mastitis in Xinjiang, China. Virus Genes 53:464-476

35. Zhou Y, Bao H, Zhang H, Wang R (2015) Isolation and Characterization of Lytic Phage vB_EcoM_JS09 against Clinically Isolated Antibiotic-Resistant Avian Pathogenic Escherichia coli and Enterotoxigenic Escherichia coli. Intervirology 58:218-231

\section{Tables}

Table 1 Host range and lytic capability of phage IME392 


\begin{tabular}{|c|c|c|c|c|}
\hline Bacteria & Strains & Relevant characteristic(s) or source & ST & Spot assay \\
\hline \multicolumn{5}{|c|}{ Escherichia coli } \\
\hline & 94 & Laboratory strain collection & 1 & +++ \\
\hline & 108 & Clinical isolates & 43 & + \\
\hline & 109 & Clinical isolates & 477 & - \\
\hline & 156 & Laboratory strain collection & 169 & + \\
\hline & 161 & ATCC25922 & 52 & - \\
\hline & 196 & Isolated from dairy farm & Non-typeable & - \\
\hline & 239 & $\mathrm{DH} 5 \mathrm{a}$ & 262 & + \\
\hline & 611 & Laboratory strain collection & 19 & +++ \\
\hline & 1186 & Clinical isolates & 8 & + \\
\hline & 1196 & Clinical isolates & 44 & - \\
\hline & 1644 & Isolated from chicken manure & 357 & + \\
\hline & 1645 & Isolated from chicken manure & Non-typeable & + \\
\hline & 1646 & Isolated from milk & 357 & +++ \\
\hline & 1647 & Isolated from milk & 466 & - \\
\hline & 1648 & Isolated from milk & 533 & - \\
\hline & 2042 & BL21 & 83 & - \\
\hline & 2621 & MG1655 & Non-typeable & +++ \\
\hline & 2724 & BL21(DE3) & 83 & - \\
\hline & 2726 & Laboratory strain collection & 945 & + \\
\hline & 2727 & Nissle1917 & 4 & - \\
\hline & 2734 & Laboratory strain collection & Non-typeable & - \\
\hline & 2735 & Laboratory strain collection & Non-typeable & - \\
\hline & 2736 & Laboratory strain collection & 88 & + \\
\hline & 2738 & Laboratory strain collection & 132 & - \\
\hline & 2739 & Laboratory strain collection & 303 & - \\
\hline & 2740 & Laboratory strain collection & 466 & - \\
\hline & 2741 & Laboratory strain collection & 24 & - \\
\hline & 2743 & Ocean University of China & Non-typeable & +++ \\
\hline \multicolumn{5}{|c|}{ Salmonella } \\
\hline & 2693 & СMCC50001 & / & - \\
\hline & 2694 & ATCC13311 & / & - \\
\hline & 2695 & ATCC14028 & / & - \\
\hline & 2696 & СMCC50115 & / & - \\
\hline & 2697 & СMCC50094 & / & - \\
\hline
\end{tabular}

+++, Clear plaques; +, plaques with slight turbidity; -, no plaque formed.

Table 2 Functional protein of bacteriophage vB_EcoM_IME392 and homology to proteins databases. 


\begin{tabular}{|c|c|c|c|c|c|c|c|c|c|c|}
\hline ORF & Start & End & Strand & Length & Top BLASTp hit & Family & Accession No. & $\begin{array}{l}\mathrm{E} \\
\text { value }\end{array}$ & $\mathrm{MW}(\mathrm{KDa})$ & pl \\
\hline 1 & 240 & 61 & - & 180 & $\begin{array}{l}\text { hypothetical protein } \\
\text { [Pectobacterium } \\
\text { brasiliense] }\end{array}$ & & WP_172644783.1 & $\begin{array}{l}6.00 \mathrm{E}- \\
16\end{array}$ & 6.70 & 4.17 \\
\hline 2 & 467 & 249 & - & 219 & Not hit & & & & 7.53 & 6.03 \\
\hline 3 & 962 & 630 & - & 333 & Not hit & & & & 12.63 & 6.50 \\
\hline 4 & 1270 & 1025 & - & 246 & hypothetical protein & & WP_063439228.1 & $\begin{array}{l}1.00 \mathrm{E}- \\
18\end{array}$ & 9.22 & 4.87 \\
\hline 5 & 1460 & 1272 & - & 189 & $\begin{array}{l}\text { DUF1653 domain- } \\
\text { containing protein } \\
\text { [Enterobacter asburiae] }\end{array}$ & & NQW57987.1 & $\begin{array}{l}1.00 \mathrm{E}- \\
07\end{array}$ & 7.43 & 6.27 \\
\hline 6 & 1645 & 1460 & - & 186 & Not hit & & & & 6.83 & 5.08 \\
\hline 7 & 1899 & 1642 & - & 258 & Not hit & & & & 9.61 & 6.27 \\
\hline 8 & 2062 & 1886 & - & 177 & Not hit & & & & 7.02 & 10.69 \\
\hline 9 & 2746 & 2117 & - & 630 & $\begin{array}{l}\text { hypothetical protein } \\
\text { [Raoultella planticola] }\end{array}$ & & WP_032697006.1 & $\begin{array}{l}5.00 \mathrm{E}- \\
46\end{array}$ & 24.17 & 5.49 \\
\hline 10 & 3642 & 2737 & - & 906 & $\begin{array}{l}\text { glycosyltransferase } \\
\text { family } 4 \text { protein } \\
\text { [Escherichia coli] }\end{array}$ & & WP_137536985.1 & $\begin{array}{l}1.00 \mathrm{E}- \\
98\end{array}$ & 34.86 & 5.66 \\
\hline 11 & 4306 & 3671 & - & 636 & $\begin{array}{l}\text { norphogenetic protein } \\
\text { [Enterobacter } \\
\text { cancerogenus] }\end{array}$ & & WP_137271981.1 & $\begin{array}{l}9.00 \mathrm{E}- \\
63\end{array}$ & 23.57 & 5.67 \\
\hline 12 & 4791 & 4270 & - & 522 & $\begin{array}{l}\text { hypothetical protein } \\
\text { [Enterobacter } \\
\text { roggenkampii] }\end{array}$ & & WP_095429045.1 & $\begin{array}{l}2.00 \mathrm{E}- \\
33\end{array}$ & 19.64 & 4.87 \\
\hline 13 & 5510 & 4803 & - & 708 & $\begin{array}{l}\text { putative membrane } \\
\text { protein [Escherichia } \\
\text { phage adrianh] }\end{array}$ & Myoviridae & QHR71453.1 & $\begin{array}{l}4.00 \mathrm{E}- \\
27\end{array}$ & 24.89 & 4.31 \\
\hline 14 & 5740 & 5510 & - & 231 & $\begin{array}{l}\text { hypothetical protein } \\
\text { [Salmonella phage } \\
\text { barely] }\end{array}$ & Ackermannviridae & YP_009888578.1 & $\begin{array}{l}1.00 \mathrm{E}- \\
17\end{array}$ & 8.50 & 7.62 \\
\hline 15 & 6106 & 5789 & - & 318 & $\begin{array}{l}\text { hypothetical protein } \\
\text { [Erwinia phage } \\
\text { vB_EamM-Bue1] }\end{array}$ & Ackermannviridae & YP_009837725.1 & $\begin{array}{l}3.00 \mathrm{E}- \\
46\end{array}$ & 12.35 & 7.63 \\
\hline 16 & 6522 & 6103 & - & 420 & $\begin{array}{l}\text { Inhibitor of host Lon } \\
\text { protease [Escherichia } \\
\text { phage EcS1] }\end{array}$ & Myoviridae & BBC78124.1 & $\begin{array}{l}2.00 \mathrm{E}- \\
08\end{array}$ & 15.65 & 4.72 \\
\hline 17 & 6742 & 6509 & - & 234 & $\begin{array}{l}\text { hypothetical protein } \\
\text { [Enterobacter phage } \\
\text { Arya] }\end{array}$ & Myoviridae & YP_009284295.1 & $\begin{array}{l}4.00 \mathrm{E}- \\
10\end{array}$ & 8.82 & 6.27 \\
\hline 18 & 7051 & 6797 & - & 255 & $\begin{array}{l}\text { acyl carrier protein } \\
\text { [Candidatus } \\
\text { Acetothermum } \\
\text { autotrophicum] }\end{array}$ & & BAL59693.1 & $\begin{array}{l}6.00 \mathrm{E}- \\
06\end{array}$ & 9.31 & 3.60 \\
\hline 19 & 8994 & 7051 & - & 1944 & $\begin{array}{l}\text { NAD-dependent DNA } \\
\text { ligase LigA [Ralstonia } \\
\text { phage RP13] }\end{array}$ & Myoviridae & BCG50031.1 & $\begin{array}{l}7.00 \mathrm{E}- \\
75\end{array}$ & 72.06 & 5.16 \\
\hline 20 & 9817 & 9059 & - & 759 & $\begin{array}{l}\text { DNA polymerase/3'-5' } \\
\text { exonuclease PolX } \\
\text { [Thermobispora bispora] }\end{array}$ & & WP_013132370.1 & $\begin{array}{l}6.00 \mathrm{E}- \\
26\end{array}$ & 28.56 & 5.86 \\
\hline 21 & 9981 & 9814 & - & 168 & Not hit & & & & 6.45 & 11.07 \\
\hline 22 & 10354 & 9983 & - & 372 & Not hit & & & & 13.82 & 5.32 \\
\hline 23 & 10473 & 10366 & - & 108 & Not hit & & & & 4.08 & 9.98 \\
\hline 24 & 10831 & 10589 & - & 243 & Not hit & & & & 9.29 & 8.85 \\
\hline 25 & 11208 & 10831 & - & 378 & Not hit & & & & 14.32 & 8.52 \\
\hline 26 & 11359 & 11198 & - & 162 & Not hit & & & & 6.21 & 6.53 \\
\hline 27 & 11565 & 11359 & - & 207 & Not hit & & & & 7.81 & 9.66 \\
\hline
\end{tabular}

Page 9/18 


\begin{tabular}{|c|c|c|c|c|c|c|c|c|c|c|}
\hline 28 & 11869 & 11573 & - & 297 & $\begin{array}{l}\text { hypothetical protein } \\
\text { [Vibrio phage } \\
\text { 1.031.O._10N.261.46.F8] }\end{array}$ & Myoviridae & AUR83081.1 & $\begin{array}{l}4.00 \mathrm{E}- \\
04\end{array}$ & 11.10 & 8.06 \\
\hline 29 & 12252 & 11872 & - & 381 & Not hit & & & & 13.92 & 4.82 \\
\hline 30 & 12573 & 12262 & - & 312 & Not hit & & & & 11.59 & 9.43 \\
\hline 31 & 13018 & 12605 & - & 414 & Not hit & & & & 14.49 & 5.11 \\
\hline 32 & 13249 & 13031 & - & 219 & Not hit & & & & 8.49 & 9.15 \\
\hline 33 & 13634 & 13260 & - & 375 & Not hit & & & & 14.01 & 5.51 \\
\hline 34 & 13978 & 13694 & - & 285 & Not hit & & & & 10.11 & 3.95 \\
\hline 35 & 14442 & 14092 & - & 351 & Not hit & & & & 13.85 & 5.76 \\
\hline 36 & 14728 & 14423 & - & 306 & Not hit & & & & 11.20 & 9.65 \\
\hline 37 & 15148 & 14804 & - & 345 & Not hit & & & & 12.43 & 5.62 \\
\hline 38 & 15659 & 15141 & - & 519 & Not hit & & & & 18.97 & 4.33 \\
\hline 39 & 15952 & 15653 & - & 300 & Not hit & & & & 11.09 & 4.32 \\
\hline 40 & 16457 & 15927 & - & 531 & $\begin{array}{l}\text { hypothetical protein } \\
\text { [Halomonas sp. S2151] }\end{array}$ & & WP_045991529.1 & $\begin{array}{l}9.00 \mathrm{E}- \\
19\end{array}$ & 19.91 & 9.23 \\
\hline 41 & 18025 & 16457 & - & 1569 & $\begin{array}{l}\text { DNA-directed RNA } \\
\text { polymerase beta } \\
\text { subunit [Ralstonia } \\
\text { phage RP13] }\end{array}$ & Myoviridae & BCG50162.1 & $\begin{array}{l}7.00 \mathrm{E}- \\
85\end{array}$ & 58.73 & 8.79 \\
\hline 42 & 18697 & 18041 & - & 657 & Not hit & & & & 24.96 & 6.44 \\
\hline 43 & 19095 & 18757 & - & 339 & Not hit & & & & 12.77 & 4.26 \\
\hline 44 & 19889 & 19203 & - & 687 & Not hit & & & & 26.59 & 8.72 \\
\hline 45 & 21418 & 19904 & - & 1515 & $\begin{array}{l}\text { DNA-directed RNA } \\
\text { polymerase beta' } \\
\text { subunit [Leptospira } \\
\text { santarosai] }\end{array}$ & & WP_075917787.1 & $\begin{array}{l}9.00 \mathrm{E}- \\
84\end{array}$ & 54.91 & 8.61 \\
\hline 46 & 21752 & 21438 & - & 315 & Not hit & & & & 12.30 & 9.47 \\
\hline 47 & 22083 & 21739 & - & 345 & Not hit & & & & 12.61 & 4.42 \\
\hline 48 & 22547 & 22080 & - & 468 & Not hit & & & & 17.66 & 6.51 \\
\hline 49 & 22918 & 22679 & - & 240 & Not hit & & & & 8.63 & 4.28 \\
\hline 50 & 24533 & 23073 & - & 1461 & Not hit & & & & 54.16 & 6.89 \\
\hline 51 & 24941 & 24672 & - & 270 & Not hit & & & & 9.66 & 10.91 \\
\hline 52 & 28209 & 24922 & - & 3288 & $\begin{array}{l}\text { DNA polymerase I } \\
\text { [Ralstonia phage RP13] }\end{array}$ & Myoviridae & BCG50106.1 & $\begin{array}{l}4.00 \mathrm{E}- \\
139\end{array}$ & 125.53 & 5.03 \\
\hline 53 & 29916 & 28279 & - & 1638 & $\begin{array}{l}\text { DEAD/DEAH box } \\
\text { helicase family protein } \\
\text { [Ralstonia phage RP13] }\end{array}$ & Myoviridae & BCG50107.1 & $\begin{array}{l}4.00 \mathrm{E}- \\
125\end{array}$ & 62.13 & 5.23 \\
\hline 54 & 30872 & 29880 & - & 993 & $\begin{array}{l}\text { hypothetical protein } \\
\text { [Ralstonia phage RP13] }\end{array}$ & Myoviridae & BCG50109.1 & $\begin{array}{l}3.00 \mathrm{E}- \\
35\end{array}$ & 38.40 & 6.28 \\
\hline 55 & 31185 & 30862 & - & 324 & Not hit & & & & 11.60 & 6.82 \\
\hline 56 & 31774 & 31175 & - & 600 & $\begin{array}{l}\text { HD domain-containing } \\
\text { protein [Ralstonia phage } \\
\text { RP13] }\end{array}$ & Myoviridae & BCG50111.1 & $\begin{array}{l}1.00 \mathrm{E}- \\
24\end{array}$ & 22.53 & 4.98 \\
\hline 57 & 32931 & 31858 & - & 1074 & $\begin{array}{l}\text { thymidylate synthase } \\
\text { [Salmonella phage } \\
\text { SeSz-1] }\end{array}$ & Ackermannvirida & YP_009881884.1 & $\begin{array}{l}2.00 \mathrm{E}- \\
51\end{array}$ & 40.37 & 5.38 \\
\hline 58 & 33650 & 32928 & - & 723 & $\begin{array}{l}\text { hypothetical protein } \\
\text { [Ralstonia phage RP13] }\end{array}$ & Myoviridae & BCG50110.1 & $\begin{array}{l}6.00 \mathrm{E}- \\
25\end{array}$ & 27.11 & 5.66 \\
\hline 59 & 34711 & 33740 & - & 972 & $\begin{array}{l}\text { hypothetical protein } \\
\text { [Ralstonia phage RP13] }\end{array}$ & Myoviridae & BCG50138.1 & $\begin{array}{l}2.00 \mathrm{E}- \\
47\end{array}$ & 38.63 & 6.03 \\
\hline 60 & 35790 & 34711 & - & 1080 & Not hit & & & & 41.14 & 5.42 \\
\hline
\end{tabular}




\begin{tabular}{|c|c|c|c|c|c|c|c|c|c|c|}
\hline 61 & 36872 & 35838 & - & 1035 & Not hit & & & & 40.12 & 5.04 \\
\hline 62 & 37490 & 36879 & - & 612 & $\begin{array}{l}\text { PIG-L family } \\
\text { deacetylase [Kocuria } \\
\text { rhizophila] }\end{array}$ & & WP_144801709.1 & $\begin{array}{l}5.00 \mathrm{E}- \\
23\end{array}$ & 23.21 & 5.25 \\
\hline 63 & 38959 & 37577 & - & 1383 & $\begin{array}{l}\text { BCCT family transporter } \\
\text { [Halomonas sp. Y2R2] }\end{array}$ & & WP_149284844.1 & $\begin{array}{l}1.00 \mathrm{E}- \\
107\end{array}$ & 50.70 & 9.21 \\
\hline 64 & 39871 & 38963 & - & 909 & Not hit & & & & 33.51 & 4.83 \\
\hline 65 & 40713 & 39973 & - & 741 & $\begin{array}{l}\text { hypothetical protein } \\
\text { [Candidatus } \\
\text { Woesearchaeota } \\
\text { archaeon] }\end{array}$ & & Ol062389.1 & $\begin{array}{l}1.00 \mathrm{E}- \\
11\end{array}$ & 27.70 & 5.03 \\
\hline 66 & 42065 & 40818 & - & 1248 & $\begin{array}{l}\text { DNA topoisomerase, } \\
\text { type IIA subunit A [Vibrio } \\
\text { phage] }\end{array}$ & Myoviridae & AUR82996.1 & $\begin{array}{l}9.00 \mathrm{E}- \\
51\end{array}$ & 46.87 & 8.17 \\
\hline 67 & 44053 & 42068 & - & 1986 & $\begin{array}{l}\text { DNA topoisomerase } \\
\text { (ATP-hydrolyzing) } \\
\text { subunit B [Thermosipho } \\
\text { atlanticus] }\end{array}$ & & WP_073073159.1 & $\begin{array}{l}8.00 \mathrm{E}- \\
54\end{array}$ & 75.27 & 5.14 \\
\hline 68 & 44527 & 44090 & - & 438 & Not hit & & & & 16.56 & 8.66 \\
\hline 69 & 44990 & 44736 & - & 255 & Not hit & & & & 9.71 & 4.81 \\
\hline 70 & 45226 & 44987 & - & 240 & Not hit & & & & 8.83 & 5.79 \\
\hline 71 & 48139 & 45374 & - & 2766 & $\begin{array}{l}\text { SMC family ATPase } \\
\text { [Ralstonia phage RP13] }\end{array}$ & Myoviridae & BCG50154.1 & 0.0 & 104.00 & 5.17 \\
\hline 72 & 48993 & 48136 & - & 858 & $\begin{array}{l}\text { DNA polymerase } \\
\text { [Bacillus phage SP-10] }\end{array}$ & Herelleviridae & YP_007003453.1 & $\begin{array}{l}3.00 \mathrm{E}- \\
12\end{array}$ & 32.56 & 5.24 \\
\hline 73 & 50056 & 49046 & - & 1011 & $\begin{array}{l}\text { hypothetical protein } \\
\text { [Ralstonia phage RP13] }\end{array}$ & Myoviridae & BCG50116.1 & $\begin{array}{l}4.00 \mathrm{E}- \\
39\end{array}$ & 37.52 & 4.77 \\
\hline 74 & 51193 & 50153 & - & 1041 & $\begin{array}{l}\text { hypothetical protein } \\
\text { [Ralstonia phage RP13] }\end{array}$ & Myoviridae & BCG50123.1 & $\begin{array}{l}4.00 \mathrm{E}- \\
07\end{array}$ & 39.79 & 5.90 \\
\hline 75 & 51417 & 51190 & - & 228 & Not hit & & & & 8.18 & 4.55 \\
\hline 76 & 51870 & 51421 & - & 450 & $\begin{array}{l}\text { hypothetical protein } \\
\text { [Ralstonia phage RP13] }\end{array}$ & Myoviridae & BCG50121.1 & $\begin{array}{l}6.00 \mathrm{E}- \\
29\end{array}$ & 17.21 & 5.05 \\
\hline 77 & 53129 & 51870 & - & 1260 & $\begin{array}{l}\text { replicative helicase } \\
\text { [Ralstonia phage RP13] }\end{array}$ & Myoviridae & BCG50120.1 & $\begin{array}{l}2.00 \mathrm{E}- \\
110\end{array}$ & 46.60 & 5.30 \\
\hline 78 & 54779 & 53139 & - & 1641 & $\begin{array}{l}\text { DEAD/DEAH box } \\
\text { helicase family protein } \\
\text { [Ralstonia phage RP13] }\end{array}$ & Myoviridae & BCG50119.1 & $\begin{array}{l}6.00 \mathrm{E}- \\
87\end{array}$ & 60.65 & 6.14 \\
\hline 79 & 55300 & 54782 & - & 519 & Not hit & & & & 19.63 & 5.32 \\
\hline 80 & 55657 & 55346 & - & 312 & Not hit & & & & 11.82 & 6.13 \\
\hline 81 & 55947 & 55702 & - & 246 & Not hit & & & & 9.16 & 9.45 \\
\hline 82 & 56254 & 55937 & - & 318 & Not hit & & & & 12.11 & 6.72 \\
\hline 83 & 57140 & 56349 & - & 792 & Not hit & & & & 31.38 & 6.15 \\
\hline \multirow[t]{3}{*}{84} & 57285 & 57163 & - & 123 & Not hit & & & & 4.62 & 9.78 \\
\hline & 58180 & 58108 & - & 73 & tRNA-Met-CAT & & & & & \\
\hline & 58725 & 58653 & - & 73 & tRNA-Arg-TCT & & & & & \\
\hline 85 & 60064 & 59522 & - & 543 & $\begin{array}{l}\text { hypothetical protein } \\
\text { [Vibrio phage PWH3a- } \\
\text { P1] }\end{array}$ & Myoviridae & YP_007675922.1 & $\begin{array}{l}8.00 \mathrm{E}- \\
41\end{array}$ & 20.84 & 7.07 \\
\hline 86 & 60343 & 60182 & - & 162 & Not hit & & & & 5.83 & 3.96 \\
\hline 87 & 60812 & 60330 & - & 483 & $\begin{array}{l}\text { putative ssDNA binding } \\
\text { protein [Pectobacterium } \\
\text { phage PP99] }\end{array}$ & Autographiviridae & YP_009788767.1 & $\begin{array}{l}7.00 \mathrm{E}- \\
41\end{array}$ & 18.26 & 7.63 \\
\hline 88 & 61153 & 60812 & - & 342 & Not hit & & & & 12.31 & 9.26 \\
\hline 89 & 61350 & 61823 & + & 474 & $\begin{array}{l}\text { hypothetical protein } \\
\text { [Ralstonia phage RP13] }\end{array}$ & Myoviridae & BCG50099.1 & $\begin{array}{l}3.00 \mathrm{E}- \\
20\end{array}$ & 16.87 & 5.34 \\
\hline
\end{tabular}




\begin{tabular}{|c|c|c|c|c|c|c|c|c|c|c|}
\hline 90 & 61827 & 63653 & + & 1827 & $\begin{array}{l}\text { terminase large subunit } \\
\text { [Vibrio phage } \\
\text { 1.031.0._10N.261.46.F8] }\end{array}$ & Myoviridae & AUR83174.1 & $\begin{array}{l}7.00 \mathrm{E}- \\
86\end{array}$ & 68.52 & 5.40 \\
\hline 91 & 63654 & 65231 & + & 1578 & $\begin{array}{l}\text { hypothetical protein } \\
\text { [Ralstonia phage RP13] }\end{array}$ & Myoviridae & BCG50094.1 & $\begin{array}{l}4.00 \mathrm{E}- \\
112\end{array}$ & 58.86 & 4.58 \\
\hline 92 & 65224 & 65478 & + & 255 & Not hit & & & & 9.16 & 4.37 \\
\hline 93 & 65491 & 66927 & + & 1437 & $\begin{array}{l}\text { hypothetical protein } \\
\text { [Ralstonia phage RP13] }\end{array}$ & Myoviridae & BCG50091.1 & $\begin{array}{l}1.00 \mathrm{E}- \\
73\end{array}$ & 52.33 & 4.70 \\
\hline 94 & 66983 & 68410 & + & 1428 & $\begin{array}{l}\text { major capsid protein } \\
\text { [Vibrio phage } \\
\text { 1.031.0._10N.261.46.F8] }\end{array}$ & Myoviridae & AUR83170.1 & $\begin{array}{l}4.00 \mathrm{E}- \\
71\end{array}$ & 50.73 & 4.74 \\
\hline 95 & 68560 & 69276 & + & 717 & Not hit & & & & 25.01 & 4.40 \\
\hline 96 & 69310 & 69846 & + & 537 & $\begin{array}{l}\text { hypothetical protein } \\
\text { [Ralstonia phage RP13] }\end{array}$ & Myoviridae & BCG50086.1 & $\begin{array}{l}3.00 \mathrm{E}- \\
39\end{array}$ & 20.16 & 9.87 \\
\hline 97 & 69846 & 70133 & + & 288 & Not hit & & & & 10.89 & 11.65 \\
\hline 98 & 70130 & 70759 & + & 630 & $\begin{array}{l}\text { hypothetical protein } \\
\text { [Ralstonia phage RP13] }\end{array}$ & Myoviridae & BCG50082.1 & $\begin{array}{l}6.00 \mathrm{E}- \\
29\end{array}$ & 23.90 & 4.78 \\
\hline 99 & 70769 & 71332 & + & 564 & Not hit & & & & 20.53 & 4.84 \\
\hline 100 & 71334 & 71999 & + & 666 & $\begin{array}{l}\text { hypothetical protein } \\
\text { [Chloroflexi bacterium] }\end{array}$ & & RLC62271.1 & $\begin{array}{l}6.00 \mathrm{E}- \\
04\end{array}$ & 24.65 & 4.71 \\
\hline 101 & 72001 & 72192 & + & 192 & Not hit & & & & 7.02 & 6.18 \\
\hline 102 & 72203 & 74002 & + & 1800 & $\begin{array}{l}\text { phage tail sheath } \\
\text { domain-containing } \\
\text { protein } \\
\text { [Pseudoalteromonas } \\
\text { citrea] }\end{array}$ & & WP_138594708.1 & $\begin{array}{l}9.00 \mathrm{E}- \\
122\end{array}$ & 64.39 & 4.80 \\
\hline 103 & 74013 & 74537 & + & 525 & $\begin{array}{l}\text { hypothetical protein } \\
\text { [Pseudoalteromonas } \\
\text { citrea] }\end{array}$ & & WP_138594710.1 & $\begin{array}{l}2.00 \mathrm{E}- \\
37\end{array}$ & 19.20 & 4.98 \\
\hline 104 & 74552 & 75028 & + & 477 & $\begin{array}{l}\text { hypothetical protein } \\
\text { [Pseudoalteromonas] }\end{array}$ & & WP_125251889.1 & $\begin{array}{l}2.00 \mathrm{E}- \\
20\end{array}$ & 18.43 & 4.90 \\
\hline 105 & 75038 & 75865 & + & 828 & $\begin{array}{l}\text { hypothetical protein } \\
\text { [Pseudoalteromonas sp. } \\
\text { McH1-7] }\end{array}$ & & WP_176033179.1 & $\begin{array}{l}2.00 \mathrm{E}- \\
28\end{array}$ & 31.11 & 5.11 \\
\hline 106 & 75944 & 78802 & + & 2859 & $\begin{array}{l}\text { glycoside hydrolase } \\
\text { [Acinetobacter } \\
\text { radioresistens] }\end{array}$ & & WP_138000971.1 & $\begin{array}{l}1.00 \mathrm{E}- \\
39\end{array}$ & 102.37 & 5.75 \\
\hline 107 & 78802 & 79437 & + & 636 & $\begin{array}{l}\text { hypothetical protein } \\
\text { [Vibrio phage } \\
\text { 1.031.0._10N.261.46.F8] }\end{array}$ & Myoviridae & AUR83149.1 & $\begin{array}{l}3.00 \mathrm{E}- \\
09\end{array}$ & 23.26 & 8.86 \\
\hline 108 & 79445 & 79822 & + & 378 & $\begin{array}{l}\text { hypothetical protein } \\
\text { [Pseudoalteromonas } \\
\text { sp.] }\end{array}$ & & NRA76876.1 & $\begin{array}{l}1.00 \mathrm{E}- \\
13\end{array}$ & 14.49 & 4.53 \\
\hline 109 & 79819 & 80943 & + & 1125 & $\begin{array}{l}\text { hypothetical protein } \\
\text { [Pseudoalteromonas } \\
\text { peptidolytica] }\end{array}$ & & WP_147390429.1 & $\begin{array}{l}1.00 \mathrm{E}- \\
34\end{array}$ & 41.96 & 8.64 \\
\hline 110 & 80946 & 81605 & + & 660 & $\begin{array}{l}\text { putative tail protein } \\
\text { [Thermus phage phiLo] }\end{array}$ & Myoviridae & AYJ73937.1 & $\begin{array}{l}7.00 \mathrm{E}- \\
19\end{array}$ & 24.15 & 5.48 \\
\hline 111 & 81613 & 81981 & + & 369 & $\begin{array}{l}\text { phage baseplate } \\
\text { assembly protein } \\
\text { [Thiovulum sp. ES] }\end{array}$ & & EJF07099.1 & $\begin{array}{l}2.00 \mathrm{E}- \\
24\end{array}$ & 14.09 & 4.96 \\
\hline 112 & 81978 & 83351 & + & 1374 & $\begin{array}{l}\text { hypothetical protein } \\
\text { [Vibrio phage } \\
\text { 1.031.0._10N.261.46.F8] }\end{array}$ & Myoviridae & AUR83140.1 & $\begin{array}{l}7.00 \mathrm{E}- \\
63\end{array}$ & 50.82 & 4.77 \\
\hline 113 & 83344 & 84822 & + & 1479 & Not hit & & & & 56.57 & 4.65 \\
\hline 114 & 84831 & 85598 & + & 768 & $\begin{array}{l}\text { hypothetical protein } \\
\text { [Planctomycetes } \\
\text { bacterium] }\end{array}$ & & RIK79130.1 & $\begin{array}{l}5.00 \mathrm{E}- \\
10\end{array}$ & 27.17 & 4.72 \\
\hline 115 & 85611 & 86528 & + & 918 & $\begin{array}{l}\text { tail spike protein } \\
\text { [Salmonella phage } \\
\text { moki] }\end{array}$ & Ackermannviridae & YP_009888731.1 & $\begin{array}{l}8.00 \mathrm{E}- \\
26\end{array}$ & 33.90 & 4.45 \\
\hline
\end{tabular}




\begin{tabular}{|c|c|c|c|c|c|c|c|c|c|c|}
\hline 116 & 86538 & 86879 & + & 342 & Not hit & & & & 11.70 & 5.62 \\
\hline 117 & 86881 & 88227 & + & 1347 & $\begin{array}{l}\text { putative tail fibers } \\
\text { protein [Salmonella } \\
\text { enterica] }\end{array}$ & & EAM1616335.1 & $\begin{array}{l}1.00 \mathrm{E}- \\
32\end{array}$ & 48.01 & 5.52 \\
\hline 118 & 88227 & 88655 & + & 429 & $\begin{array}{l}\text { tail fiber assembly } \\
\text { protein [Escherichia sp. } \\
\text { ESNIH1] }\end{array}$ & & WP_103819369.1 & $\begin{array}{l}2.00 \mathrm{E}- \\
20\end{array}$ & 16.11 & 4.29 \\
\hline 119 & 88667 & 90118 & + & 1452 & $\begin{array}{l}\text { putative phage collar } \\
\text { protein [Escherichia coli] }\end{array}$ & & STL39829.1 & $\begin{array}{l}3.00 \mathrm{E}- \\
64\end{array}$ & 52.33 & 5.59 \\
\hline 120 & 90118 & 90726 & + & 609 & $\begin{array}{l}\text { tail fiber assembly } \\
\text { protein [Escherichia coli] }\end{array}$ & & WP_181193511.1 & $\begin{array}{l}2.00 \mathrm{E}- \\
50\end{array}$ & 23.01 & 4.45 \\
\hline 121 & 90802 & 91425 & + & 624 & $\begin{array}{l}\text { tail fiber protein } \\
\text { [Escherichia coli] }\end{array}$ & & HAJ7147756.1 & $\begin{array}{l}1.00 \mathrm{E}- \\
38\end{array}$ & 23.10 & 8.75 \\
\hline 122 & 91505 & 94492 & + & 2988 & $\begin{array}{l}\text { tail fibers protein } \\
\text { [Salmonella phage } \\
\text { IME207] }\end{array}$ & Siphoviridae & YP_009322784.1 & 0.0 & 111.33 & 5.41 \\
\hline 123 & 94616 & 97237 & + & 2622 & $\begin{array}{l}\text { colanic acid-degrading } \\
\text { protein [Cronobacter } \\
\text { phage } \\
\text { vB_CsaM_GAP32] }\end{array}$ & Myoviridae & YP_006987233.1 & $\begin{array}{l}1.00 \mathrm{E}- \\
125\end{array}$ & 94.96 & 5.17 \\
\hline 124 & 97262 & 98713 & + & 1452 & $\begin{array}{l}\text { hypothetical protein } \\
\text { [Gimesia algae] }\end{array}$ & & QDT94270.1 & $\begin{array}{l}1.00 \mathrm{E}- \\
07\end{array}$ & 52.14 & 6.16 \\
\hline 125 & 98730 & 99551 & + & 822 & $\begin{array}{l}\text { hypothetical protein } \\
\text { [Klebsiella variicola] }\end{array}$ & & WP_135714845.1 & $\begin{array}{l}6.00 \mathrm{E}- \\
20\end{array}$ & 29.48 & 5.10 \\
\hline 126 & 99563 & 102607 & + & 3045 & $\begin{array}{l}\text { DUF4815 domain- } \\
\text { containing protein } \\
\text { [Syntrophobacteraceae } \\
\text { bacterium] }\end{array}$ & & NSW86778.1 & $\begin{array}{l}9.00 \mathrm{E}- \\
145\end{array}$ & 109.48 & 4.71 \\
\hline 127 & 102617 & 102793 & + & 177 & Not hit & & & & 6.68 & 8.19 \\
\hline 128 & 102818 & 103465 & + & 648 & $\begin{array}{l}\text { putative endolysin } \\
\text { [Burkholderia phage } \\
\text { BcepSaruman] }\end{array}$ & Myoviridae & YP_009904215.1 & $\begin{array}{l}1.00 \mathrm{E}- \\
66\end{array}$ & 24.33 & 9.20 \\
\hline 129 & 103480 & 103896 & + & 417 & $\begin{array}{l}\text { hypothetical protein } \\
\text { [Aeromonas } \\
\text { enteropelogenes] }\end{array}$ & & WP_042027513.1 & $\begin{array}{l}3.00 \mathrm{E}- \\
11\end{array}$ & 15.06 & 5.39 \\
\hline 130 & 103900 & 104130 & + & 231 & Not hit & & & & 8.50 & 5.34 \\
\hline 131 & 104199 & 104531 & + & 333 & Not hit & & & & 12.70 & 5.06 \\
\hline 132 & 104826 & 104584 & - & 243 & Not hit & & & & 9.33 & 4.90 \\
\hline 133 & 105380 & 104826 & - & 555 & Not hit & & & & 20.84 & 5.02 \\
\hline 134 & 105739 & 105377 & - & 363 & $\begin{array}{l}\text { cell wall hydrolase } \\
\text { [Pseudomonas panacis] }\end{array}$ & & WP_154841641.1 & $\begin{array}{l}2.00 \mathrm{E}- \\
20\end{array}$ & 13.86 & 10.12 \\
\hline 135 & 106148 & 105771 & - & 378 & Not hit & & & & 13.62 & 4.93 \\
\hline 136 & 106784 & 106161 & - & 624 & $\begin{array}{l}\text { putative dCTP } \\
\text { deaminase } \\
\text { [Dehalococcoidia } \\
\text { bacterium] }\end{array}$ & & MXY43540.1 & $\begin{array}{l}7.00 \mathrm{E}- \\
15\end{array}$ & 23.66 & 6.51 \\
\hline 137 & 106966 & 106784 & - & 183 & Not hit & & & & 6.85 & 4.90 \\
\hline 138 & 107522 & 107052 & - & 471 & $\begin{array}{l}\text { dUTP diphosphatase } \\
\text { [Shewanella } \\
\text { donghaensis] }\end{array}$ & & WP_144212174.1 & $\begin{array}{l}4.00 \mathrm{E}- \\
61\end{array}$ & 16.83 & 5.09 \\
\hline 139 & 107899 & 107519 & - & 381 & $\begin{array}{l}\text { hypothetical protein } \\
\text { [Acidobacteria } \\
\text { bacterium] }\end{array}$ & & MBF84480.1 & $\begin{array}{l}2.00 \mathrm{E}- \\
35\end{array}$ & 14.60 & 7.08 \\
\hline 140 & 108123 & 107899 & - & 225 & Not hit & & & & 8.01 & 12.02 \\
\hline 141 & 108464 & 108162 & - & 303 & $\begin{array}{l}\text { hypothetical protein } \\
\text { [Klebsiella phage } \\
\text { Muenster] }\end{array}$ & Myoviridae & QOE32388.1 & $\begin{array}{l}2.00 \mathrm{E}- \\
16\end{array}$ & 11.14 & 9.12 \\
\hline 142 & 109188 & 108475 & - & 714 & $\begin{array}{l}\text { putative } 3^{\prime}-5^{\prime} \\
\text { exoribonuclease } \\
\text { [Pseudomonas peli] }\end{array}$ & & WP_090248742.1 & $\begin{array}{l}6.00 \mathrm{E}- \\
07\end{array}$ & 27.41 & 5.08 \\
\hline
\end{tabular}




\begin{tabular}{|c|c|c|c|c|c|c|c|c|c|c|}
\hline 143 & 109606 & 109253 & - & 354 & Not hit & & & & 13.31 & 5.44 \\
\hline 144 & 109838 & 109599 & - & 240 & hypothetical protein & & WP_157760109.1 & $\begin{array}{l}6.00 \mathrm{E}- \\
08\end{array}$ & 8.90 & 10.49 \\
\hline 145 & 110066 & 109893 & - & 174 & hypothetical protein & & WP_001563024.1 & $\begin{array}{l}1.00 \mathrm{E}- \\
17\end{array}$ & 6.60 & 4.34 \\
\hline 146 & 110549 & 110085 & - & 465 & $\begin{array}{l}\text { NADAR family protein } \\
\text { [Delftia acidovorans] }\end{array}$ & & NIT77307.1 & $\begin{array}{l}8.00 \mathrm{E}- \\
31\end{array}$ & 17.84 & 8.78 \\
\hline 147 & 111118 & 110549 & - & 570 & $\begin{array}{l}\text { hypothetical protein } \\
\text { [Klebsiella phage } \\
\text { ZCKP1] }\end{array}$ & Myoviridae & YP_009803533.1 & $\begin{array}{l}2.00 \mathrm{E}- \\
21\end{array}$ & 22.48 & 5.48 \\
\hline 148 & 111362 & 111108 & - & 255 & Not hit & & & & 9.35 & 9.21 \\
\hline 149 & 111536 & 111372 & - & 165 & Not hit & & & & 6.24 & 9.39 \\
\hline 150 & 111729 & 111577 & - & 153 & Not hit & & & & 5.66 & 3.85 \\
\hline 151 & 111910 & 111716 & - & 195 & $\begin{array}{l}\text { hypothetical protein } \\
\text { [Vibrio phage } \\
\text { vB_VchM_Kuja] }\end{array}$ & Ackermannviridae & YP_009854103.1 & $\begin{array}{l}6.00 \mathrm{E}- \\
08\end{array}$ & 7.66 & 4.44 \\
\hline 152 & 112204 & 111971 & - & 234 & Not hit & & & & 8.61 & 7.96 \\
\hline 153 & 112904 & 112734 & - & 171 & $\begin{array}{l}\text { hypothetical protein } \\
\text { [Citrobacter phage } \\
\text { Merlin] }\end{array}$ & Myoviridae & YP_009203833.1 & $\begin{array}{l}2.00 \mathrm{E}- \\
04\end{array}$ & 6.31 & 6.53 \\
\hline 154 & 113256 & 112897 & - & 360 & Not hit & & & & 13.74 & 5.67 \\
\hline 155 & 113600 & 113367 & - & 234 & $\begin{array}{l}\text { hypothetical protein } \\
\text { [Klebsiella phage } \\
\text { vB_KpnM_KpS110] }\end{array}$ & Ackermannviridae & YP_009798919.1 & $\begin{array}{l}4.00 \mathrm{E}- \\
08\end{array}$ & 8.38 & 4.57 \\
\hline 156 & 114141 & 113611 & - & 531 & $\begin{array}{l}\text { LysM peptidoglycan- } \\
\text { binding domain- } \\
\text { containing protein }\end{array}$ & & WP_094245731.1 & $\begin{array}{l}6.00 \mathrm{E}- \\
04\end{array}$ & 20.10 & 6.82 \\
\hline 157 & 114497 & 114159 & - & 339 & Not hit & & & & 13.19 & 4.56 \\
\hline 158 & 114724 & 114497 & - & 228 & Not hit & & & & 8.39 & 6.11 \\
\hline 159 & 115275 & 114721 & - & 555 & $\begin{array}{l}\text { hypothetical protein } \\
\text { [Klebsiella oxytoca 10- } \\
5244]\end{array}$ & & KMV90563.1 & $\begin{array}{l}5.00 \mathrm{E}- \\
26\end{array}$ & 20.62 & 5.86 \\
\hline 160 & 115696 & 115286 & - & 411 & $\begin{array}{l}\text { hypothetical protein } \\
\text { [Cronobacter phage } \\
\text { CR9] }\end{array}$ & Myoviridae & YP_009015051.1 & $\begin{array}{l}3.00 \mathrm{E}- \\
13\end{array}$ & 15.52 & 6.04 \\
\hline 161 & 115874 & 115686 & - & 189 & Not hit & & & & 6.89 & 4.04 \\
\hline 162 & 116130 & 115933 & - & 198 & Not hit & & & & 7.21 & 4.44 \\
\hline
\end{tabular}

Table 3 Characteristic of the vB_EcoM_IME392 virion proteome identified by LC-MS/MS 


\begin{tabular}{|c|c|c|c|c|c|c|c|}
\hline $\begin{array}{l}\text { CDS } \\
\text { No. }\end{array}$ & $\begin{array}{l}\text { Molecular } \\
\text { mass (kDa) }\end{array}$ & $\begin{array}{l}\text { No. of Unique } \\
\text { Peptides }\end{array}$ & $\begin{array}{l}\text { No. of Unique } \\
\text { Spectra }\end{array}$ & $\begin{array}{l}\text { Coverage } \\
(\%)\end{array}$ & Predicted function & Abundance & iBAQ \\
\hline 48 & 50.699 & 11 & 180 & $33.05 \%$ & putative major capsid protein & 54692.29223 & 2878.541696 \\
\hline 3 & 23.553 & 4 & 8 & $28.44 \%$ & putative morphogenic protein & 6750.338238 & 843.7922797 \\
\hline 22 & 40.343 & 6 & 18 & $25.49 \%$ & putative thymidylate synthase & 51649.30422 & 2347.695646 \\
\hline 53 & 64.349 & 10 & 88 & $24.21 \%$ & putative tail sheath protein & 25463.46055 & 943.0911316 \\
\hline 76 & 24.319 & 5 & 8 & $22.79 \%$ & putative lysis protein & 21046.06895 & 1315.379309 \\
\hline 65 & 33.880 & 4 & 19 & $22.62 \%$ & putative tail fibers protein & 23590.13879 & 1387.655223 \\
\hline 31 & 46.839 & 7 & 19 & $22.17 \%$ & $\begin{array}{l}\text { putative DNA topoisomerase } \\
\text { subunit A }\end{array}$ & 32046.70718 & 1144.525257 \\
\hline 81 & 16.686 & 2 & 5 & $20.00 \%$ & putative dUTP diphosphatase & 3151.507709 & 315.1507709 \\
\hline 32 & 75.226 & 7 & 19 & $19.06 \%$ & $\begin{array}{l}\text { putative DNA topoisomerase } \\
\text { subunit B }\end{array}$ & 18602.95892 & 489.5515504 \\
\hline 8 & 28.546 & 3 & 7 & $18.25 \%$ & $\begin{array}{l}\text { putative DNA-directed DNA } \\
\text { polymerase family X }\end{array}$ & 5244.725872 & 374.6232766 \\
\hline 68 & 52.295 & 5 & 14 & $17.60 \%$ & putative collar fiber protein & 18607.30015 & 744.292006 \\
\hline 19 & 62.092 & 6 & 15 & $16.70 \%$ & putative DNA helicase & 19464.30079 & 648.8100263 \\
\hline 1 & 24.150 & 2 & 5 & $16.27 \%$ & putative morphogenic protein & 6115.22847 & 436.8020336 \\
\hline 66 & 47.984 & 4 & 17 & $12.95 \%$ & putative tail fibers protein & 6728.588573 & 373.8104763 \\
\hline 71 & 111.264 & 10 & 35 & $12.76 \%$ & putative endosialidase tailspike & 41860.88542 & 872.1017796 \\
\hline 39 & 46.568 & 4 & 7 & $12.41 \%$ & putative DNA helicase & 32529.96823 & 1355.415343 \\
\hline 69 & 22.999 & 1 & 16 & $11.39 \%$ & putative tail fiber assembly protein & 2197.969707 & 199.8154279 \\
\hline 18 & 125.445 & 10 & 25 & $10.59 \%$ & putative DNA polymerase I & 56612.4992 & 870.9615262 \\
\hline 80 & 23.642 & 2 & 9 & $10.14 \%$ & putative dCTP deaminase & 1812.964954 & 129.4974967 \\
\hline 70 & 23.087 & 2 & 3 & $9.66 \%$ & putative tail fibers protein & 6499.410564 & 464.2436117 \\
\hline 72 & 94.901 & 7 & 12 & $8.71 \%$ & putative colanidase tailspike & 19163.57878 & 491.373815 \\
\hline 7 & 72.014 & 4 & 8 & $6.65 \%$ & putative DNA ligase & 17073.1183 & 474.2532861 \\
\hline 12 & 58.693 & 3 & 7 & $5.56 \%$ & $\begin{array}{l}\text { putative DNA-directed RNA } \\
\text { polymerase beta' subunit }\end{array}$ & 10412.92608 & 359.0664165 \\
\hline 15 & 54.876 & 2 & 3 & $5.56 \%$ & $\begin{array}{l}\text { putative DNA-directed RNA } \\
\text { polymerase beta' subunit }\end{array}$ & 4614.473378 & 128.1798161 \\
\hline 57 & 102.312 & 4 & 4 & $5.36 \%$ & putative glycoside hydrolase & 21515.99538 & 352.7212358 \\
\hline 2 & 32.959 & 1 & 2 & $4.56 \%$ & putative glycosyltransferase & 5288.362023 & 278.3348433 \\
\hline 35 & 32.535 & 1 & 1 & $4.56 \%$ & putative 5'-3' DNA exonuclease & 2315.063498 & 136.1802058 \\
\hline 40 & 60.611 & 1 & 1 & $1.65 \%$ & putative DNA helicase & 8802.824665 & 352.1129866 \\
\hline
\end{tabular}

\section{Figures}




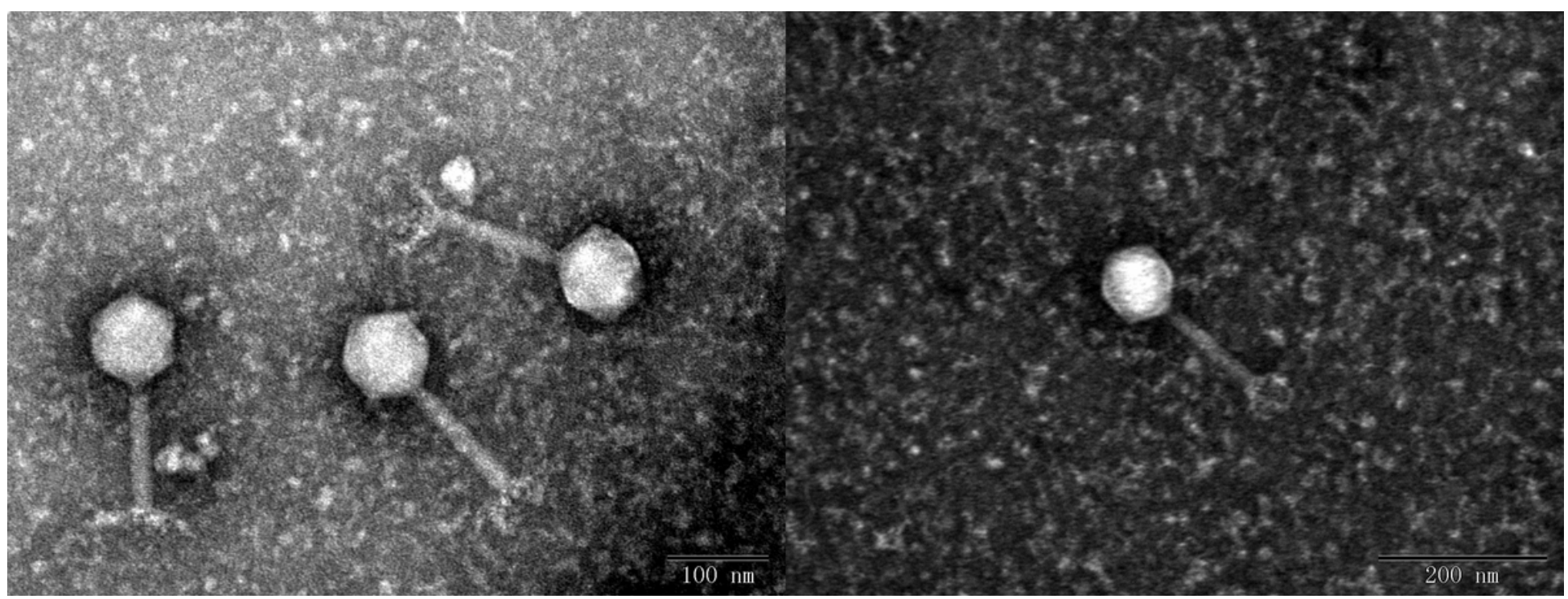

Figure 1

Morphological Features of Bacteriophage vB_EcoM_IME392. IME392 possess an icosahedral head of approximately $83.93 \pm 0.55 \mathrm{~nm}$ in diameter and a contractile tail of $122.23 \pm 3.55 \mathrm{~nm}$ in length $(\mathrm{n}=10)$.

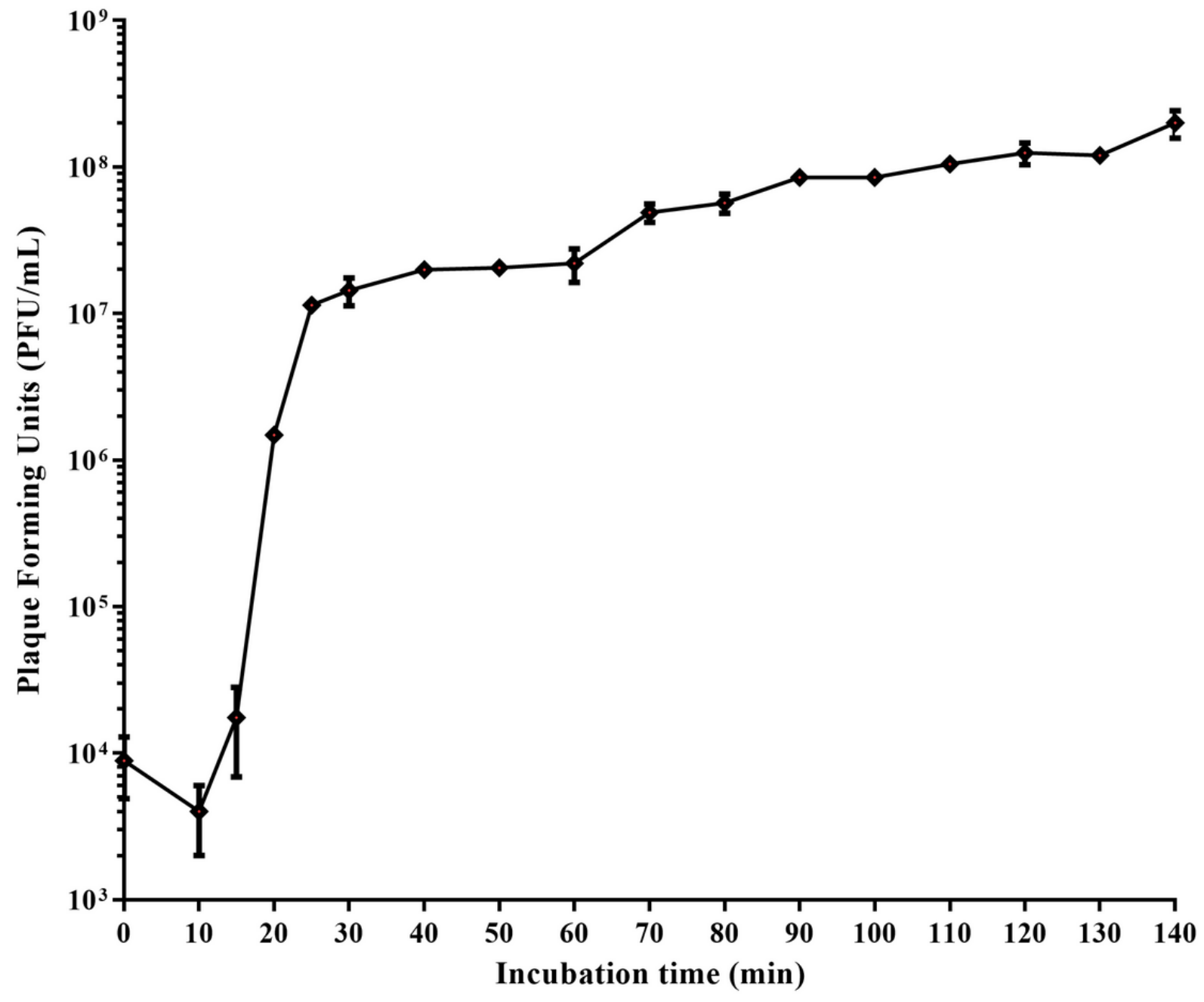

Figure 2

One-step Growth Curve of Bacteriophage vB_EcoM_IME392. The latent period and burst period of IME392 are both approximately 15 minutes. 

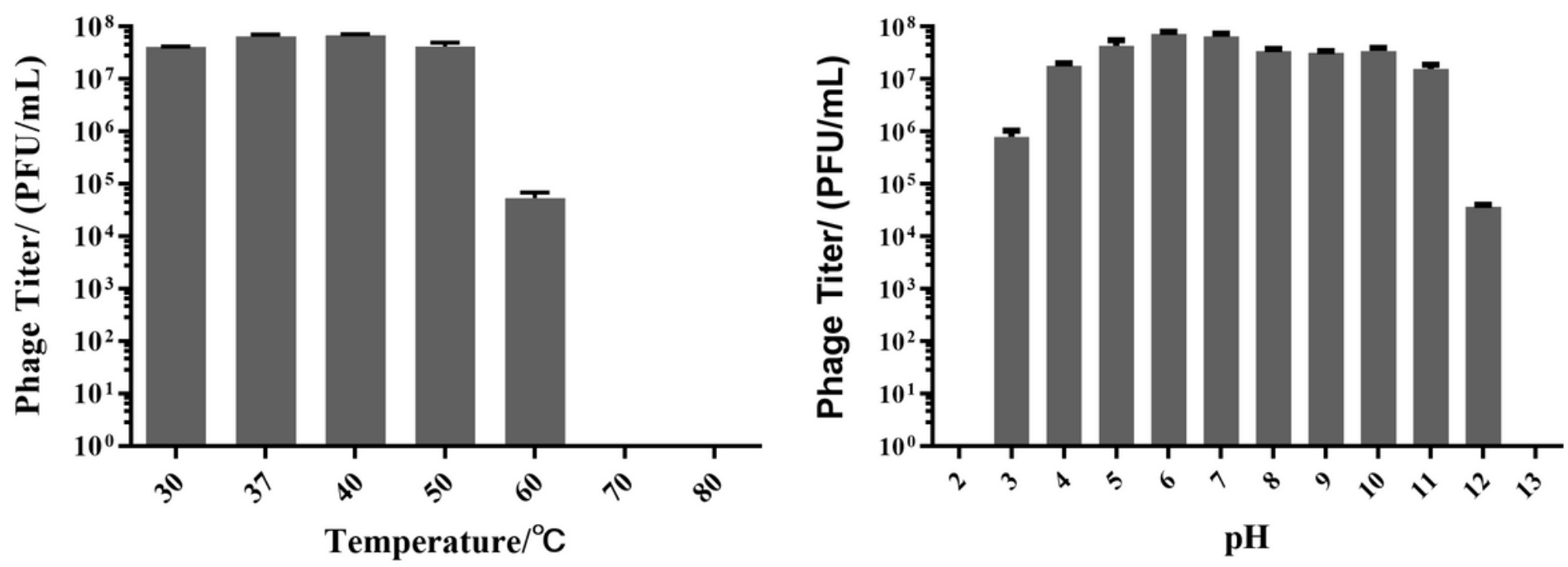

Figure 3

The temperature and pH stability of Bacteriophage vB_EcoM_IME392. IME392 is extremely sensitive to heat treatment. Incubating up to $60{ }^{\circ} \mathrm{C}$ for 1 hour is able to reduce phage titer by $99.94 \%$, while no phage titer was observed if the incubation temperature reached $70^{\circ} \mathrm{C}$ or higher $(3 \mathrm{~A})$. It is also sensitive to both low and high $\mathrm{pH}$ environment. No phage titer was detected when the phage particles were incubated in $\mathrm{pH}=2.0$ or 13.0 environment at $37^{\circ} \mathrm{C}$ for 1 hour (3B).

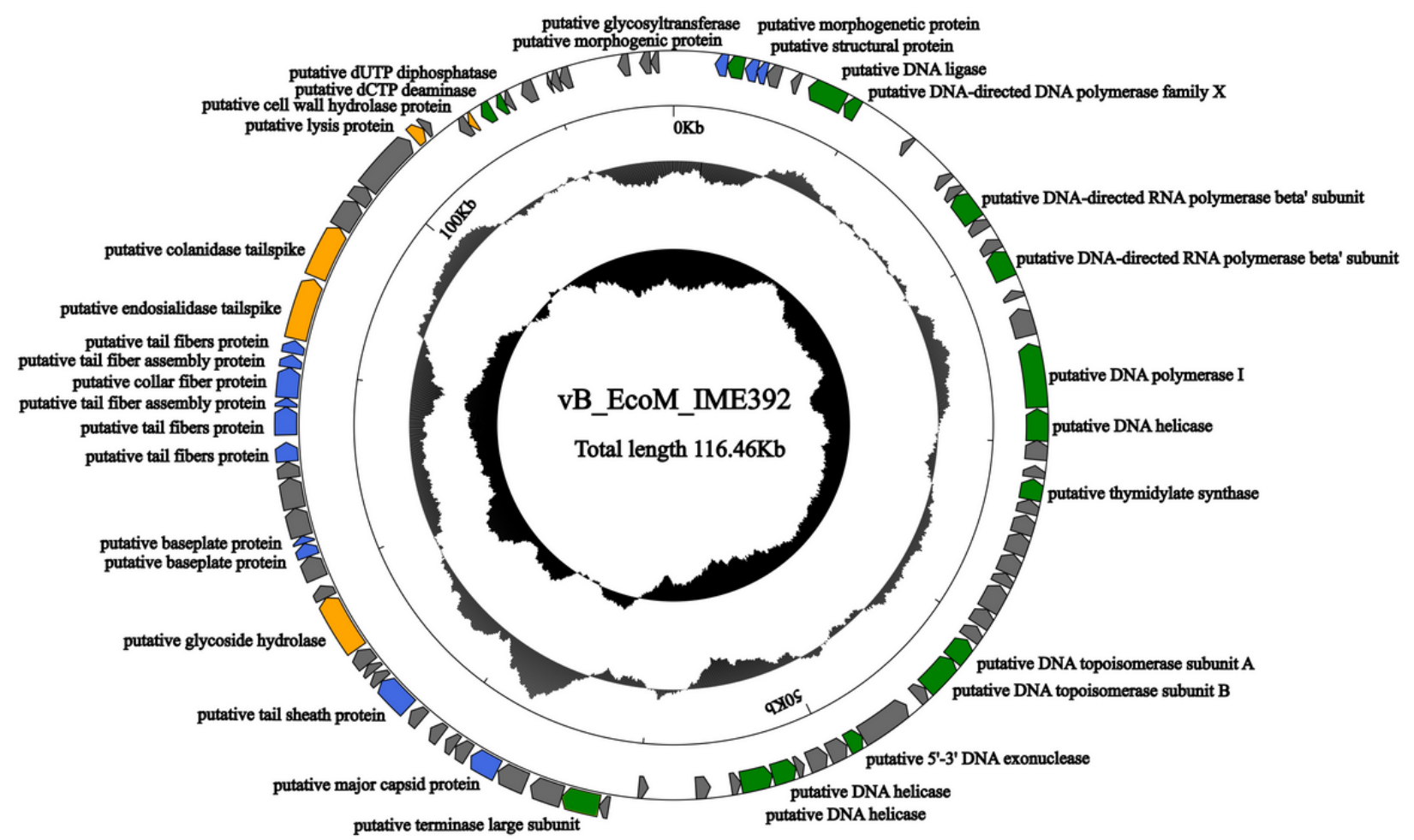

Figure 4 
The genome function map of Bacteriophage vB_EcoM_IME392. The outermost circle represents the gene coding region. The arrows indicate the direction of transcription of each gene. Different colors refer to different functional categories: hypothetical protein (gray), lysis-related protein (yellow), phage morphogenesis protein (blue), replication and regulation-related protein (green). The two innermost circles represent $\mathrm{GC}-\mathrm{skew}[(\mathrm{G}-\mathrm{C})$ / (G+C)] and $\mathrm{G}+\mathrm{C}$ content. The gray circle represents the $\mathrm{G}+\mathrm{C}$ content. The outward direction indicates that the $\mathrm{G}+\mathrm{C}$ content of this region is larger than the average $\mathrm{G}+\mathrm{C}$ content of the whole genome, and the inward direction indicates that the $\mathrm{G}+\mathrm{C}$ content of that region is lower than the average $\mathrm{G}+\mathrm{C}$ content. The black circle represents the GC-skew $[(\mathrm{G}-\mathrm{C}) /(\mathrm{G}+\mathrm{C})]$. The outward direction indicates that the $\mathrm{GC}$-skew $[(\mathrm{G}-\mathrm{C}) /(\mathrm{G}+\mathrm{C})]$ is larger than zero, and the inward direction indicates that the $\mathrm{GC}$-skew $[(\mathrm{G}-\mathrm{C}) /(\mathrm{G}+\mathrm{C})]$ is lower than zero. The scale units are base pairs.
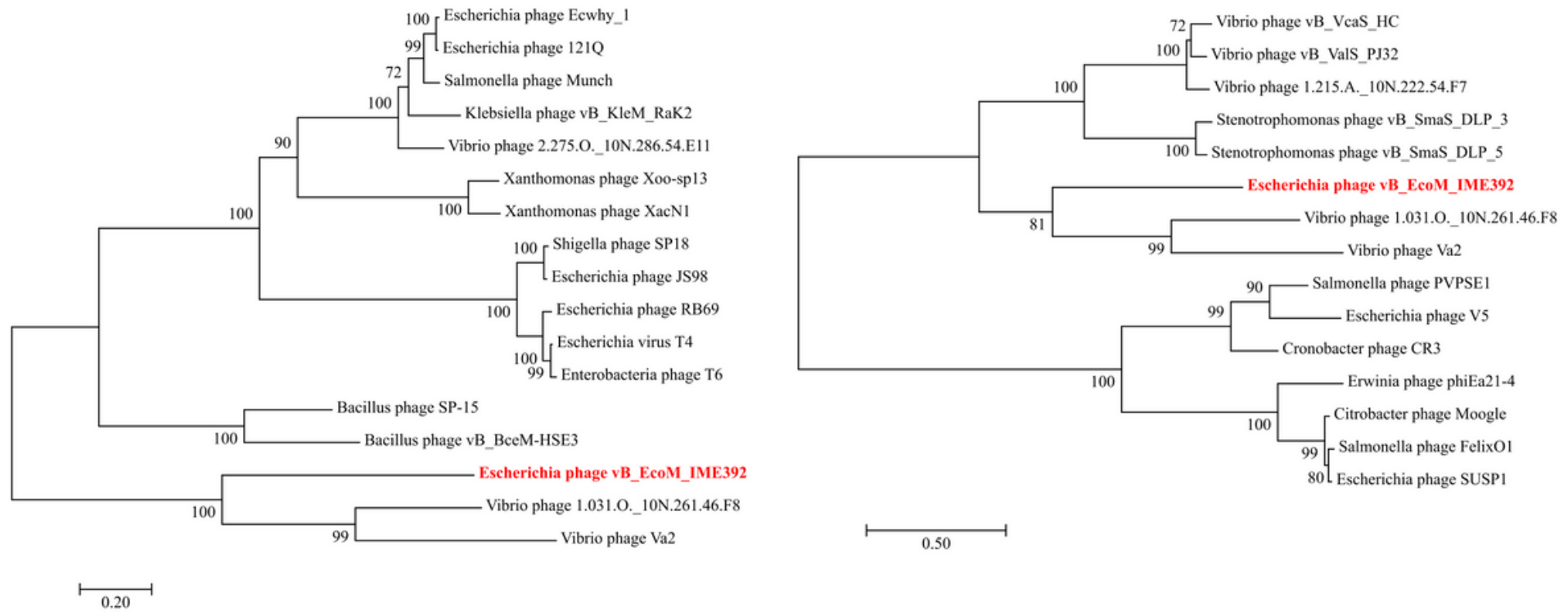

\section{Figure 5}

Phylogenetic analysis of phages in different genus of Myoviridae family based on their major capsid proteins (A) and terminase large subunit (B). Phylogenetic trees were constructed using the neighbor-joining method with 1000 bootstrap replications.

\section{Supplementary Files}

This is a list of supplementary files associated with this preprint. Click to download.

- SupplementaryTable120210405.doc 